\title{
Hybrid Inflation Targeting Regimes
}

\author{
Carlos Garcia', Jorge Restrepo 3 , Scott Roger,
}

\begin{abstract}
This paper uses a DSGE model to examine whether including the exchange rate explicitly in the central bank's policy reaction function can improve macroeconomic performance. It is found that including an element of exchange rate smoothing in the policy reaction function is helpful both for financially robust advanced economies and for financially vulnerable emerging economies in handling risk premium shocks. As long as the weight placed on exchange rate smoothing is relatively small, the effects on inflation and output volatility in the event of demand and cost-push shocks are minimal. Financially vulnerable emerging economies are especially likely to benefit from some exchange rate smoothing because of the perverse impact of exchange rate movements on activity.
\end{abstract}

JEL Classification Numbers: E42, E52, F41

Keywords: Inflation targeting, monetary policy, exchange rate

\footnotetext{
${ }^{1}$ We would like to thank colleagues and seminar participants at the Central Bank of Chile, the Catholic University of Chile, and the IMF for many helpful comments and suggestions. Thanks also to Eduardo Sepúlveda for his help with the coding of the model.

${ }^{2}$ ILADES—Universidad Alberto Hurtado, Santiago, Chile: cgarcia@uahurtado.cl.

${ }^{3}$ Central Bank of Chile: jrestrep@bcentral.cl.

${ }^{4}$ International Monetary Fund: sroger@imf.org.
} 


\section{INTRODUCTION}

1. For many emerging economies that have either adopted inflation targeting (IT) monetary policy frameworks, or are considering doing so, the appropriate role of the exchange rate in the framework is a sensitive and difficult issue. Particularly for countries where the exchange rate has previously played a key role as an anchor for policy, there is a reluctance to move to a completely free float. An important issue for such countries, therefore, is whether or how to take the exchange rate into account in an IT framework.

2. The purpose of this paper is to contribute to the growing literature on adapting IT frameworks to the circumstances of emerging economies. The paper uses small, stylized models of a financially vulnerable emerging economy and a financially robust advanced economy to compare the performance of alternative policy rules in handling demand, costpush, and risk premium shocks. The results suggest that, for financially robust advanced economies, putting a small weight on exchange rate smoothing is beneficial in handling risk premium shocks, with no significant adverse consequences for inflation or output performance. For financially vulnerable emerging economies, the benefits of some exchange rate smoothing are found to be even more beneficial, largely reflecting the perverse effects of exchange rate movements on demand in financially vulnerable economies.

3. The paper is organized as follows. Section II begins with a review of relevant literature on open economy inflation targeting. Section III outlines taxonomy of alternative approaches to bringing the exchange rate into the IT framework. Section IV develops small models of a financially-robust advanced economy and a financially-vulnerable emerging economy. Section $\mathrm{V}$ reports on the simulations of the models using alternative policy rules and in response to alternative shocks. Section VI concludes with a discussion of the robustness of the results and areas for future research.

\section{INFLATION TARGETING IN AN OPEN ECONOMY}

4. Until relatively recently, most research on the conduct of IT in an open economy focused mainly on models with standard industrial country open economy characteristics, reflecting the fact that much of the research was focused on the industrial countries that pioneered inflation targeting. ${ }^{5}$ In his review of the literature to that point, Taylor (2001) finds little evidence to support including the exchange rate explicitly in the central bank's policy reaction function, and suggests that this may reflect: (i) the fact that exchange rate movements are already taken into account indirectly in a standard IT framework; and (ii) that the appropriate response to the exchange rate depends on the nature of the underlying shock. Nonetheless, Taylor (2000), Mishkin (2000) and, more recently Edwards (2007), all

\footnotetext{
${ }^{5}$ Including New Zealand, Canada, the United Kingdom, Sweden, and Australia.
} 
underscore the need for further research in this area, particularly in relation to emerging economies.

5. More recent research on inflation targeting policy rules provides mixed evidence on whether to include the exchange rate directly in the reaction function. One avenue of research has been on whether financial vulnerabilities may justify including the exchange rate in the reaction function. Céspedes and others (2000), Morón and Winkelried (2005), and Cavoli and Rajan (2006), suggest that there may be some benefit from including the exchange rate in the reaction function in financially-vulnerable economies, but also find that the optimal weight is low. However, Batini and others (2007), using a model of the fairly heavily dollarized Peruvian economy, conclude that no weight should be put on the exchange rate in a financially-vulnerable economy, and argue that because dollarization weakens the output gap channel of transmission relative to the exchange rate channel, nothing should be done to limit the flexibility of the exchange rate in order to achieve the inflation target.

6. Other authors consider the implications for IT frameworks in emerging economies of other structural features of emerging markets. Ravenna and Natalucci (2008) find that significant smoothing of the exchange rate has adverse macroeconomic consequences when there are substantial Balassa-Samuelson effects resulting from differential productivity growth in the tradables and nontradables sectors. McCallum (2006), however, finds that an exchange rate based approach to IT may be beneficial in a very open economy such as that of Singapore.

7. Another avenue of investigation focuses on the implications of uncertainty regarding the transmission mechanisms in the economy, and may be particularly relevant to emerging economies. Leitemo and Söderstöm (2005) consider the choice of policy rules when there is uncertainty about the true model of exchange rate determination, and find that a standard reaction function is slightly more robust than one including the exchange rate.

Wollmershäuser (2006), however, comes to the opposite conclusion after examining a wider range of rules and types of exchange rate uncertainty.

8. Support for dampening exchange rate movements is also found in the presence of incomplete exchange rate pass-through (pricing to market), ${ }^{6}$ as well as in the event of sector specific shocks with imperfect substitutability of consumption across goods. ${ }^{7}$

\section{Model Characteristics ANd Calibration}

9. In this section, a small open economy Dynamic Stochastic General Equilibrium (DSGE) model is developed to evaluate the performance of alternative IT approaches in

\footnotetext{
${ }^{6}$ See e.g., Devereux and Engel (2003) and Corsetti and Pesenti (2005).

${ }^{7}$ See e.g., Tille (2002)
} 
financially-robust advanced economies and financially-vulnerable emerging market economies. The section begins with a description of the model, followed by a discussion of the calibration of two versions of the model; one with the characteristics of an "advanced" economy with high policy credibility and well-functioning financial markets; the other an "emerging market" economy with limited policy credibility, limited domestic financial market development, and external financial vulnerability. The section concludes with a brief description of the behavior of key variables in response to different kinds of shocks.

\section{The small open economy model}

10. The model used in this paper to analyze alternative monetary policy rules is a fairly conventional small open economy New Keynesian DSGE model. These models embody a synthesis of the modeling approach of the real business cycle literature and micro foundations for Keynesian concepts. ${ }^{8}$ Such models have essentially neoclassical long-run characteristics - notably including monetary neutrality — but Keynesian short-term characteristics, providing scope for monetary policy to affect the real economy over the short- to medium-term. An important feature of the model used here, is that it abstracts from the determination of the steady state of the economy, as well as permanent shocks that change the steady state. It focuses on the dynamics of the return to the steady state following macroeconomic disturbances.

11. The model includes several features which are aimed at capturing some characteristics of financially-vulnerable emerging market economies. These include:

- Explicit inclusion of the exchange rate in the central bank policy reaction function (Cavoli and Rajan, 2006; Kirsanova, Campbell and Wren-Lewis, 2006);

- Weak policy credibility and endogenous, history-dependent expectations formation (Erceg and Levin, 2003; Argov and others, 2007);

- $\quad$ An endogenous risk premium (following Céspedes, Chang, and Velasco, 2002), increasing in external indebtedness and the exchange rate;

- Limited intertemporal arbitrage in consumption (following Amato and Laubach, 2003; Galí, Lopez-Salido, and Vallés, 2004, 2006), to reflect the relatively undeveloped domestic financial systems in many emerging markets;

- $\quad$ Perverse exchange rate effects on income (following Morón and Winkelried, 2005) to reflect adverse balance sheet effects;

- Different timing of exchange rate pass-through to costs and prices (Monacelli, 2004); and

\footnotetext{
${ }^{8}$ Good overviews of the synthesis of approaches are found in Goodfriend and King (1995), Clarida, Galí and Gertler (1999), and Galí and Gertler (2007).
} 
- $\quad$ An exported natural resource, providing scope for terms of trade shocks.

12. The log-linearized equations included in the model are as follows:

\section{Aggregate spending}

13. Optimizing Ricardian consumption is derived from a standard separable utility function on consumption $C_{t}$ and labor $N_{t}$ :

$U\left(C_{t}, N_{t}\right)=\frac{\left(C_{t}-\gamma C_{t-1}\right)^{1-\sigma}-1}{1-\sigma}-N_{t}^{v}$

where:

$\sigma$ is the coefficient of relative risk aversion;

$\gamma$ is the degree of habit formation in consumption. This introduces an element of inertia into consumption, and is a fairly standard feature of New Keynesian models.

14. The first order conditions of utility maximization provide the Euler equation that guides consumption: ${ }^{9}$

$$
\hat{c}_{t}^{o}=(\gamma / 1+\gamma) \hat{c}_{t-1}^{o}+(1 / 1+\gamma) \hat{c}_{t+1}^{o}-(1-\gamma / 1+\gamma) 1 / \sigma\left[\left(\hat{i}_{t}\right)-\hat{\pi}_{t+1}\right]
$$

where:

$\hat{c}_{t}^{o}$ is the optimized level of consumption in period $t$, relative to the steady state level of consumption. ${ }^{10}$

$\hat{i}_{t}$ is the current nominal interest rate

$\hat{\pi}_{t+1}$ is the inflation rate expected in period $t+1$

15. The other part of real consumer spending, $\hat{c}_{t}^{r}$, is based on current income. The share of such consumption, $\lambda$, described as "rule of thumb" or non-Ricardian consumption, is likely to be higher in many emerging market economies than in more advanced economies, reflecting the more limited access of some households to borrowing and savings

\footnotetext{
${ }^{9}$ See Appendix I for a derivation of Equation 2.

${ }^{10}$ I.e., $\hat{c}_{t}$, represents the (log) deviation of the level of the variable $C_{t}$ from its steady state or long-run value, $\bar{C}_{t}$.
} 
opportunities. ${ }^{11}$ To the extent that this constraint holds, real spending is driven by real wages and employment :

$\hat{c}_{t}^{r}=\hat{w}_{t}-\hat{p}_{t}+\hat{n}_{t}$

where:

$\hat{w}_{t}$ is the nominal wage rate per unit of work supplied

$\hat{p}_{t}$ is the price level

$\hat{n}_{t}$ is the number of units of work supplied

16. In addition to domestic demand, there is also foreign demand for the domestically produced good, $\hat{x}_{t}^{d}$. Export demand depends on foreign real income and the real exchange rate:

$\hat{x}_{t}^{d}=\rho_{x^{d}} \hat{t}_{t-1}^{d}+\left(1-\rho_{x^{d}}\right)\left[\tau \hat{q}_{t}+\hat{y}_{t}^{*}\right]$

where:

$\hat{y}_{t}^{*}$ is foreign real income

$\hat{q}_{t}$ is the real exchange rate (the real cost of foreign currency)

$\rho_{x^{d}}$ is the degree of persistence in domestically-produced exports

$\tau$ is the real exchange rate elasticity of demand for domestically-produced exports

17. Aggregate spending on the domestically produced good, $\hat{y}_{t}^{d}$, is composed of domestic spending, $\hat{c}_{t}$, plus exports, $\hat{x}_{t}^{d}$ :

$$
\hat{y}_{t}^{d}=\frac{\bar{c}}{\bar{y}^{d}} \hat{c}_{t}+\frac{\bar{x}^{d}}{\bar{y}^{d}} \hat{x}_{t}^{d}
$$

Where:

$\frac{\bar{c}}{\bar{y}^{d}}$ and $\frac{\bar{x}^{d}}{\bar{y}^{d}}$ represent the respective shares of consumption and exports in domestic output in the steady state.

18. A fraction, $\lambda$, of domestic spending is credit-constrained or "rule-of-thumb" (nonRicardian) consumption, $\hat{c}_{t}^{r}$, while the rest is inter-temporally optimized (Ricardian) consumption, $\hat{c}_{t}^{o}$ :

\footnotetext{
${ }^{11}$ This may reflect limited development of financial systems (lack of suitable product ranges or limited retail branch development) or legal weaknesses inhibiting collateralization of borrowing. See, e.g., Galí, LopezSalido, and Vallés $(2004,2007)$.
} 


$$
\hat{c}_{t}=\lambda \hat{c}_{t}^{r}+(1-\lambda) \hat{c}_{t}^{o}
$$

\section{Aggregate production}

19. Output in the economy consists of two types of goods. The first is a composite good produced by monopolistically competitive firms both for domestic consumption and also for export. The second good is a natural endowment commodity which is exported.

20. The domestically-produced composite good, $\hat{y}_{t}^{d}$, is produced using a CES production technology with inputs of labor, $\hat{n}_{t}$, and an imported input, $I_{t}$. This production function is particularly convenient because of its generality, given that it embeds a CobbDouglas or even a Leontief technology, depending on the size of the elasticity of input substitution, $\sigma_{s}$ :

$\hat{y}_{t}^{d}=(1-\alpha)^{\sigma_{S}} \hat{n}_{t}+(\alpha)^{\sigma_{S}} \hat{I}_{t}+\left((1-\alpha)^{\sigma_{S}}+(\alpha)^{\sigma_{S}}\right) \hat{a}_{t}$

where:

$\sigma_{s}$ is the elasticity of substitution in production

$I_{t}$ is the imported intermediate input

$\hat{n}_{t}$ is the labor input

$\alpha$ is the share of the imported good in production - the openness of the economy

$\hat{a}_{t}$ is total factor productivity

21. Production costs reflect the costs of the labor and the imported inputs, as well as labor. The real cost of imported inputs is determined by the real exchange rate, $\hat{q}_{t}$, while the real wage, $\left(\hat{w}_{t}-\hat{p}_{t}\right)$, is determined by the equilibration of producers' demand for labor, $\hat{n}_{t}$, with the supply of labor by households. The supply of labor by fully optimizing consumers is derived from maximization of utility in equation (3). Non-Ricardian consumers are assumed to supply the same amount of labor as Ricardians. ${ }^{12}$ Aggregate supply depends positively on real wage and negatively on consumption. This is a typical result obtained from the first order condition with respect to labor of separable utility functions: ${ }^{13}$

\footnotetext{
${ }^{12}$ This assumption follows Galí, López-Salido, and Vallés (2007).

${ }^{13}$ See Appendix I for derivation of equation 8.
} 


$$
\hat{n}_{t}=\frac{1}{(v-1)}\left\{\left(\hat{w}_{t}-\hat{p}_{t}\right)-\sigma\left[(1 / 1-\gamma) \hat{c}_{t}-(\gamma / 1-\gamma) \hat{c}_{t-1}\right]\right\}
$$

where:

$v$ is the coefficient of disutility of labor

22. With the production technology specified in equation (7), the log deviation of the real marginal cost of production, $\hat{m} c_{r}^{R}$, is given by:

$$
\hat{m} c_{r}^{R}=(1-\alpha)^{\sigma_{s}}\left(\hat{w}_{t}-\hat{p}_{t}\right)+\alpha^{\sigma_{s}} \hat{q}_{t}-\left[(1-\alpha)^{\sigma_{s}}+\alpha^{\sigma_{s}}\right] \hat{a}_{t}
$$

where:

$\hat{w}_{t}$ is the nominal wage rate per unit of work supplied

$\hat{p}_{t}$ is the price level

$\hat{q}_{t}$ is the real exchange rate (the real cost of foreign currency)

23. Equation (9) shows that the more open the economy-i.e., the higher the value of $\alpha$-the larger the impact of exchange rate movements on production costs and inflation. The elasticity of substitution in production, $\sigma_{s}$, also plays an important role: the lower the possibility of substituting domestic labor for imported inputs, the larger the impact of an exchange rate movement on costs.

24. Firms set the price of the domestically-produced good in one of two ways. One group of firms, accounting for a fraction $\mu$ of domestic sales, follows a simple, backwardlooking approach to price setting. ${ }^{14}$ In effect, this leads to an element of indexation of prices generating persistence in inflation. All other firms take a forward-looking optimization approach to price setting, but adjust their prices on a random basis, à la Calvo. In any given period, it is assumed that only a fraction $(1-\theta)$ of the optimizing firms adjust their prices.

25. Taking these considerations into account, the aggregate inflation rate in the economy will be summarized by a New Keynesian Phillips curve of the form:

$$
\hat{\pi}_{t}=\left(\frac{\beta}{1+\beta \mu}\right) \hat{\pi}_{t+1}+\left(\frac{\mu}{1+\beta \mu}\right) \hat{\pi}_{t-1}+\left(\frac{\varsigma}{1+\beta \mu}\right) \hat{m} c_{r}^{R}
$$

where:

$\beta$ is the subjective rate of time preference

$\mu$ is the proportion of price adjustment based on indexation to past prices

${ }^{14}$ See Smets and Wouters (2002). 
$\varsigma=\frac{1-\theta}{\theta}(1-\beta \theta)$, where $(1-\theta)$ is the average frequency of price adjustment by optimizing firms

$\hat{m} c_{r}^{R}$ is the real marginal cost of production ${ }^{15}$

26. This Phillips curve has three elements. The first is an expected inflation component. This reflects the assumption that firms adjust their prices periodically rather than continuously, so that when prices are adjusted, firms take into account the expected evolution of inflation. The second term is a lagged inflation component reflecting the indexation applied to a fraction $\mu$ of prices. The third term reflects the incorporation of marginal costs into optimizing firms' prices. Exchange rate movements feed into inflation through their impact on marginal costs. The speed of pass-through into inflation will depend both on the proportion of optimizing firms and on the average frequency of price adjustments.

27. Production of the second endowment type good, $\hat{x}_{t}^{C M}$, is essentially exogenous, and is completely exported. The amount produced of this commodity does not react to its price, and the requirement for local inputs to its production is negligible. Its value depends on the real exchange rate and its price, $\bar{p}_{t}^{C M}$, abroad which is given by international markets.

Consequently, the value of production is determined as:

$\hat{x}_{t}^{C M}=\hat{q}_{t}+\hat{p}_{t}^{C M}$

\section{Exchange rate determination}

28. The real exchange rate is assumed to be determined by the real uncovered interest parity condition, the lagged exchange rate, and a risk premium: ${ }^{16}$

$\hat{q}_{t}=\left(1-\phi^{s}\right) \hat{q}_{t+1}+\phi^{s} \hat{q}_{t-1}-\left(\hat{i}_{t}-\hat{\pi}_{t+1}\right)+\left(\hat{i}_{t}^{*}-\hat{\pi}_{t+1}^{*}\right)+\hat{\phi}_{t}$

where:

$\hat{q}_{t}=\hat{s}_{t}+\hat{p}_{t}^{*}-\hat{p}_{t}$ is the real exchange rate $\left(\hat{s}_{t}\right.$ is the spot price of foreign exchange, and $\hat{p}_{t}^{*}$ is the foreign price level

$\phi^{s}$ is the degree of persistence in the real exchange rate

$\hat{i}_{t}^{*}$ is the foreign nominal interest rate

\footnotetext{
${ }^{15}$ See Appendix I for the derivation of firms' marginal cost.

${ }^{16}$ The inclusion of a lagged exchange rate term follows Berg, Karam, and Laxton (2006), who justify adding this term on the basis that it yields more realistic dynamics
} 
$\hat{\pi}_{t+1}^{*}$ is the expected foreign inflation rate
$\hat{\phi}_{t}$ is the risk premium

29. Following Céspedes, Chang, and Velasco (2002), the risk premium, $\hat{\phi}_{t}$, depends on debt, the external current balance, and balance sheet effects of currency movements: ${ }^{17}$

$$
\hat{\phi}_{t}=\phi_{0}\left(\hat{b}_{t+1}^{*}-\hat{y}_{t}\right)-\phi_{1}\left[\frac{\bar{x}^{d}}{\bar{x}^{d}+\bar{x}^{C M}} \hat{x}_{t}^{d}+\left(\frac{\bar{x}^{C M}}{\bar{x}^{d}+\bar{x}^{C M}}-1\right) \hat{q}_{t}\right]+\phi_{2}\left(\hat{I}_{t}\right)+\phi_{3}\left(\hat{q}_{t}\right)
$$

where:

$\hat{b}_{t+1}^{*}$ is projected external debt in period $t+1$

$\hat{y}_{t}$ is total production, defined in equation (15), and as in equation (4) exports is:

$\hat{x}_{t}^{d}=\tau \hat{q}_{t}+\hat{y}_{t}^{*}$ if $\rho_{x^{d}}=0$ or $\hat{x}_{t}^{d}=\rho_{x^{d}} \hat{x}_{t-1}^{d}+\left(1-\rho_{x^{d}}\right)\left[\tau \hat{q}_{t}+\hat{y}_{t}^{*}\right]$ if $0<\rho_{x^{d}}<1$

30. The risk premium consists of four elements:

- $\quad$ The first term in the equation, $\phi_{0}\left(\hat{b}_{t+1}^{*}-\hat{y}_{t}\right)$, says that the risk premium is an increasing function of the external debt-to-total production ratio. This friction in the international capital markets is required to ensure stationarity of the external debt-to-total production ratio. ${ }^{18}$

- $\quad$ The second and third terms, $-\phi_{1}\left((\tau-1) \hat{q}_{t}+\hat{y}_{t}^{*}\right)+\phi_{2}\left(\hat{I}_{t}\right)$, relate the risk premium negatively to exports (driven by foreign demand and competitiveness) and positively to imports, so that a weakening of the current account raises the risk premium.

- $\quad$ The last term, $\phi_{3}\left(\hat{q}_{t}\right)$, captures the adverse impact of currency depreciation on the domestic currency value of external debt - the balance sheet effect. As the debt service burden on borrowers rises, the risk premium increases. For a financially vulnerable economy, the adverse impact of depreciation through the balance sheet effect must outweigh the beneficial effects of depreciation on the current account, so that depreciation has a net harmful effect on activity. This imposes restrictions on the values of the parameters in the risk premium equation. ${ }^{19}$

\footnotetext{
${ }^{17}$ See also Morón and Winkelried (2005). Gertler, Gilchrist and Natalucci (2003) develop a closely related alternative to modeling this risk premium.

${ }^{18}$ See Schmidt-Grohé and Uribe (2003).

${ }^{19}$ See Céspedes, Chang, and Velasco (2002) and Morón and Winkelried (2005).
} 


\section{Monetary policy}

31. Monetary policy is described by the alternative reaction functions presented in Section III.

\section{Monetary policy credibility}

32. The approach to incorporating monetary policy credibility in this paper assumes that the central bank is a well-behaved inflation targeter, in the sense that it does not change the inflation target according to actual inflation outcomes. ${ }^{20}$ However, private agents may not fully believe this. Instead, they may believe that the central bank adjusts the target, to some extent, in response to deviations of inflation outcomes from the perceived target. The deviation of the perceived inflation target from the actual target, $\bar{\pi}_{t}^{P}$, is assumed to evolve according to:

$$
\bar{\pi}_{t}^{P}=\rho_{p} \bar{\pi}_{t-1}^{P}+\left(1-\rho_{p}\right) \kappa\left(\pi_{t-1}-\bar{\pi}_{t-1}^{P}\right)
$$

33. A highly credible regime is interpreted as one in which the value of $\rho$ is high, while the value of $\kappa$ is low, so that the target is perceived as stable, and only very large deviations of actual inflation from target will shift perceptions of the future target. In a regime with low credibility, the opposite holds: $\rho_{p}$ is low and $\kappa$ is high, so that the perceived inflation target moves relatively strongly in response to recent inflation outcomes. Because the parameters determining policy credibility are exogenous, the central bank cannot through its actions affect the degree of policy credibility. However, it can take its credibility into account when setting policy.

34. The misperception of the inflation target affects the economy through several channels. Following Argov and others (2007), these include effects on consumption (via the perceived real rate of interest), inflation (via inflation expectations), and the real exchange rate (via the perceived real interest rate). As a consequence, the Euler equation, Phillips curve, and real interest parity equations presented earlier are modified, as follows:

The modified consumption equation:

$\hat{c}_{t}^{o}=(\gamma / 1+\gamma) \hat{c}_{t-1}^{o}+(1 / 1+\gamma) \hat{c}_{t+1}^{o}-(1-\gamma / 1+\gamma) 1 / \sigma\left[\left(\hat{i}_{t}\right)-\left(\hat{\pi}_{t+1}+\psi \bar{\pi}_{t}^{P}\right)\right]$

The modified inflation equation:

\footnotetext{
${ }^{20}$ This differs from Erceg and Levin (2003), who assume that the inflation target does in fact change over time, but not in a way that can be readily observed by the public.
} 
$\hat{\pi}_{t}=\left(\frac{\beta}{1+\beta \mu}\right)\left(\hat{\pi}_{t+1}+\psi \bar{\pi}_{t}^{P}\right)+\left(\frac{\mu}{1+\beta \mu}\right) \hat{\pi}_{t-1}+\left(\frac{\varsigma}{1+\beta \mu}\right) \hat{m} c_{r}^{R}$

And the modified exchange rate equation:

$\hat{q}_{t}=\left(1-\phi^{s}\right) \hat{q}_{t+1}+\phi^{s} \hat{q}_{t-1}+\left(\hat{i}_{t}^{*}-\hat{\pi}_{t+1}^{*}\right)-\left(\hat{i}_{t}-\left(\hat{\pi}_{t+1}+\psi \bar{\pi}_{t}^{P}\right)\right)+\hat{\phi}_{t}$

35. These equations incorporate lack of credibility whenever $\psi>0$. The perception bias passes fully to inflation expectations in the exchange rate equation, but only partially feeds into the consumption equation and inflation equations. Consequently, in this framework the foreign exchange market is more sensitive to lack of credibility than is inflation itself.

\section{Equilibrium conditions and identities}

36. Total output of the economy is the sum of the domestic consumption and exports of the domestically produced good, together with the exports of the exported endowment commodity:

$$
\hat{y}_{t}=\frac{\bar{c}}{\bar{y}} \hat{c}_{t}+\frac{\bar{x}^{d}}{\bar{y}} \hat{x}_{t}^{d}+\frac{\bar{x}^{C M}}{\bar{y}} \hat{x}_{t}^{C M}
$$

where:

$\frac{\bar{c}}{\bar{y}}, \frac{\bar{x}^{d}}{\bar{y}}$ and $\frac{\bar{x}^{C M}}{\bar{y}}$ are shares of consumption, exports of domestically produced good, and exports of the endowment commodity, in total production.

Note that GDP is equal to total output minus imports:

$$
G \hat{D} P_{t}=\hat{y}_{t}-\alpha_{y} \frac{\bar{y}^{d}}{\bar{y}}\left(\hat{I}_{t}+\hat{q}_{t}\right)
$$

37. The balance of payments or economy-wide constraint is built adding up the consumer, government, and firm resource constraints:

$$
\begin{aligned}
& \frac{\bar{c}}{\bar{y}} \hat{c}_{t}=\hat{y}_{t}-\alpha_{y} \frac{\bar{y}^{d}}{\bar{y}}\left(\hat{I}_{t}+\hat{q}_{t}\right) \\
& +\frac{\bar{b}^{*}}{\bar{y}} \frac{1}{\left(1+\bar{i}^{*}\right) \bar{\phi}}\left[\pi_{t+1}^{*}+\hat{b}_{t+1}^{*}-\left(\hat{q}_{t+1}-\hat{q}_{t}\right)-\left(1 \hat{+}_{t}^{*}\right)-\hat{\phi}_{t}\right] \\
& -\frac{\bar{b}^{*}}{\bar{y}} \hat{b}_{t}^{*}
\end{aligned}
$$

38. The net change in foreign debt should be equal to the current account, which is composed of the trade balance and interest payments abroad. 


\section{Calibration of "advanced" and "emerging economy" models}

39. Two versions of the model are calibrated. The first is a stylized representation of a financially robust "advanced," economy where there is full credibility of the central bank's commitment to the inflation target. The second economy is a financially vulnerable "emerging" economy, where the commitment to the inflation target has only limited credibility. These features are reflected in the calibration of the models as follows: ${ }^{21}$

- Domestic financial system development: In the emerging economy, it is assumed that households have more limited access to borrowing and savings opportunities than in an advanced economy. As a result, spending will be more closely linked to current income and less sensitive to interest rates. To capture these effects, it is assumed that in the emerging economy only 70 percent of consumption is based on intertemporal optimization, while 30 percent is based on current income. In the advanced economy, it is assumed that all consumption is based on optimization.

- $\quad$ Balance sheet vulnerability: In many emerging economies, a significant part of corporate and household financial liabilities are denominated in foreign currency, creating a direct exposure of balance sheets to exchange rate movements. To capture this vulnerability, it is assumed that the currency risk premium in the emerging economy is positively related to the exchange rate. ${ }^{22}$ As a result, depreciation of the home currency worsens balance sheet positions, leading to an increase in the risk premium.

- External financial constraints: The emerging economy is also assumed to face more constrained access to international capital markets than does the advanced economy. As a consequence, the emerging economy's country risk premium is assumed to be much more sensitive to the external debt/GDP ratio and the trade balance than in the advanced economy.

- $\quad$ Policy credibility. In the advanced economy, the central bank's commitment to the inflation target is treated as fully credible. In the emerging economy, however, policy is less than fully credible. As a result, in the emerging economy, deviations of inflation from target have a larger and more persistent impact on inflation expectations, price setting, consumption, and the real exchange rate.

\footnotetext{
${ }^{21}$ The calibration of the model is described in more detail in Appendix II.

22 This approach to modeling external financial vulnerability follows Céspedes, Chang, and Velasco (2000); and Morón and Winkelried (2005).
} 


\section{A TAXonomy OF Hybrid Inflation TARgeting APPROACHES}

40. This section outlines a taxonomy of approaches bringing the exchange rate into the IT framework. These comprise: (i) the standard open economy IT framework- "plain vanilla" IT - in which exchange rate movements are taken into account only indirectly; (ii) an open-economy approach which includes the exchange rate explicitly in the central bank's policy reaction function; (iii) IT with an explicit exchange rate band; and (iv) IT with the exchange rate rather than a short-term interest rate as the policy instrument or operating objective.

41. These approaches have three important features in common. The first is that stabilizing inflation around the target rate is the over-riding policy objective over the longterm. ${ }^{23}$ Second, the central bank may also seek to reduce the volatility of output, interest rates, and the exchange rate, but it must do so in a way that is consistent with the mediumterm inflation target. ${ }^{24}$ Third, the different rules involve a systematic approach to policy, in the sense that the elements in the central bank's policy reaction function and the weights placed on the different elements are stable over time.

\section{"Plain vanilla" inflation targeting in an open economy}

42. The "plain vanilla" approach describes the orthodox IT framework practiced in advanced countries. ${ }^{25}$ Monetary policy formulation involves periodic adjustments in a target policy interest rate, guided primarily by deviations of projected inflation from the target and, to a lesser extent, by the deviation of actual GDP from the sustainable rate (the "output gap"). Typically, the central bank also seeks to smooth the path of interest rates. This approach to policy formulation is captured by the policy reaction function:

$\hat{i}_{t}=\rho_{i} \hat{i}_{t-1}+\left(1-\rho_{i}\right)\left[\delta \hat{\pi}_{t}+\varphi \hat{y}_{t}\right]+v_{t}$

Where:

\footnotetext{
${ }^{23}$ Essentially this requires that the policy instrument reacts strongly enough to a gap between the inflation forecast and the target to ensure that inflation will return to the target rate over the long-term.

${ }^{24}$ In this context, it is important to distinguish clearly between targets and objectives. The central bank has an inflation target, but it has no target for either output or the exchange rate (either in level or rate of change). This is distinct from the objective of minimizing variations of inflation around the target, and of output, interest rates, and the exchange rate around their steady state values. The output and exchange rate objectives, however, need to be cast in terms of deviations from exogenous steady state values to be consistent with the inflation target.

${ }^{25}$ See e.g., Mishkin (2000) and Truman (2003) for overviews of the framework, and Svensson (2000) for a model-based analysis of policy formulation.
} 
$\hat{i}_{t} \equiv i_{t}-\left(\bar{r}+\pi^{T}\right)$ is the deviation of policy target interest rate $i_{t}$ in period $t$, from its long-run steady-state value, defined as the long-run equilibrium real interest rate $\bar{r}$, plus the target inflation rate $\pi^{T}$; $\hat{\pi}_{t} \equiv\left(\pi_{t}^{f}-\pi^{T}\right)$ is the deviation of the period $t$ inflation forecast, $\pi_{t}^{f}$, from the inflation target $\pi^{T}$;

$\hat{y}_{t} \equiv\left(y_{t}-\bar{y}_{t}\right)$ is the deviation of real output $y_{t}$ from $\bar{y}_{t}$, the estimated level of potential output, in period $t$;

$v_{t}$ represents additional policy judgment as well as imprecision in policy implementation.

43. Key features of the plain vanilla reaction function are:

- The exchange rate does not appear explicitly in the policy reaction function. However, exchange rate developments and prospects are taken into account implicitly because they affect the inflation forecasts and output. ${ }^{26}$

- To ensure that the central bank's actions are consistent with achieving the inflation target, the value of $\delta$ should be greater than 1, so that the real interest rate changes by at least as much as any change in deviation of projected inflation from target. ${ }^{27}$

- $\quad$ Although the central bank does not have a long run target for the level of output or growth, it places some weight on dampening output volatility around the sustainable, noninflationary level of output ("potential" output), to ensure long-run consistency with the primary inflation objective. ${ }^{28}$

- $\quad$ The parameter $\rho_{i}$ characterizes the degree of policy inertia. If $\rho_{i}$ is high, the central bank will normally adjust the policy stance only gradually in response to economic developments or prospects.

\section{Open-economy inflation targeting}

44. “Open-economy” IT involves taking exchange rate developments explicitly into account in the central bank's policy reaction function, rather than just indirectly though the effects on output and the inflation forecast. In practice, many IT countries - both advanced and emerging economies - appear to adjust interest rates systematically in response to

\footnotetext{
${ }^{26}$ See e.g., Brook (2002), Ragan (2005), and Taylor (2001).

${ }^{27}$ The distinction between "strict" and "flexible" IT discussed in Svensson (2000) partly hinges on whether $\delta$ is much greater than $\varphi$ or not.

${ }^{28}$ Caution is needed in interpreting the weights in the reaction function. These do not necessarily reflect the central bank's preferences regarding stable inflation versus other objectives. For example, even if the central bank had no interest in stabilizing output per se, it might still put some weight on dampening output volatility if this contributed to stabilizing inflation.
} 
exchange rate movements, consistent with an open-economy IT approach. ${ }^{29}$ The way in which the exchange rate enters the reaction function is essentially similar to the way that output is included: there is no target for the exchange rate, but some weight is placed on dampening exchange rate volatility: ${ }^{30}$

$\hat{i}_{t}=\rho_{i} \hat{i}_{t-1}+\left(1-\rho_{i}\right)\left[\delta \hat{\pi}_{t}+\varphi \hat{y}_{t}+\chi\left(\hat{q}_{t}-\eta \hat{q}_{t-1}\right)\right]+v_{t}$

Where $\hat{q}_{t}$ is the deviation of the real exchange rate in period $t$ from its steady state equilibrium value.

45. This specification allows for dampening volatility in the level of the exchange rate relative to the long-run equilibrium value, changes in the exchange rate, or both:

- If $\eta=0$, the central bank systematically dampens deviations of the level of the real exchange rate from the steady state equilibrium rate. ${ }^{31}$ Alternatively, if $\eta=1$, the central bank dampens changes in the real exchange rate, consistent with limiting exchange rate volatility.

- $\quad$ More generally, if $0<\eta<1$, the central bank places some weight on dampening rapid changes in the exchange rate as well as on limiting exchange rate misalignment.

46. Including the exchange rate in the reaction function does not imply setting a exchange rate target. Indeed, it is essential that dampening exchange rate volatility be conducted in a manner that is consistent with the noninflationary long-term equilibrium of the economy. This is particularly important if the policy responds to deviations of the level of the exchange rate from the estimated steady state value, since errors in estimating the long-term equilibrium level may lead to systematic bias in the stance of policy, and a conflict between the inflation and exchange rate objectives. ${ }^{32}$

\footnotetext{
${ }^{29}$ See e.g., Mohanty and Klau (2004), Frommel and Schobert (2006), Leiderman and others (2006), Wei (2008), and Aizenman and Hutchison (2008).

${ }^{30}$ See e.g., Ball (2000), Batini and others (2001), and Taylor (2001).

${ }^{31}$ Note that the steady state value of the real exchange rate may have an upward or downward trend over time, particularly in emerging market economies experiencing significant structural change.

${ }^{32}$ Of course, this applies equally to dampening fluctuations in the level of output relative to the estimated level of potential output.
} 


\section{Inflation targeting with an exchange rate band}

47. IT with an exchange rate band involves setting limits on the acceptable range of movement of the exchange rate. In the case of a symmetric exchange rate band, the policy reaction function can be represented as: ${ }^{33}$

$\hat{i}_{t}=\rho_{i} \hat{i}_{t-1}+\left(1-\rho_{i}\right)\left[\delta \hat{\pi}_{t}+\varphi \hat{y}_{t}+(\chi+\psi)\left(\hat{q}_{t}-\eta \hat{q}_{t-1}\right)\right]+v_{t}$

Where:

$\psi=0$ if $\left|\hat{q}_{t}\right|<q^{\prime}$

$$
\psi>>0 \text { if }\left|\hat{q}_{t}\right| \geq q^{\prime}
$$

$q^{\prime}$ is half the width of the exchange rate band.

48. Within the band, the approach will work essentially as the open economy IT approach, but once the edge of the band is reached the inflation objective will be overridden by the exchange rate objective. ${ }^{34}$ Clearly, if the exchange rate band is wide relative to the typical magnitude of exchange rate changes, then the band will rarely be binding, and the approach will be similar to open-economy IT. If the band is relatively narrow, however, the regime may appear similar to an exchange rate peg (a crawling peg if the equilibrium exchange rate is moving over time or some kind of peg to a composite if the real effective exchange rate is used). The nonlinearity of the response of policy to exchange rate movements that is implied by this framework is difficult to incorporate in a simple model, and for this reason is not included in the model simulations.

\section{Exchange rate-based inflation targeting}

49. The exchange rate rather than an interest rate can be used as the operating instrument or proximate target for monetary policy. ${ }^{35}$ In this case, the central bank's policy reaction function can be described as:

$\hat{q}_{t}=\rho_{q} \hat{q}_{t-1}+\left(1-\rho_{q}\right)\left[\delta \hat{\pi}_{t}+\varphi \hat{y}_{t}\right]+v_{t}$

\footnotetext{
${ }^{33}$ See Morón and Winkelried (2005).

${ }^{34}$ As long as the deviation of the real exchange rate from the steady state equilibrium, $\hat{q}_{t}$, is less than some amount $q^{\prime}$, then policy will be based on an open-economy IT approach (or plain vanilla if the exchange rate coefficient $\chi$ is set to zero). However, if the exchange rate reaches the $q^{\prime}$ threshold, then the interest rate response to further exchange rate deviation, $(\chi+\psi)$, will be much stronger, over-riding the inflation objective.

${ }^{35}$ See Parrado (2004) and MacCallum (2006) for analyses of this approach to Singaporean monetary policy.
} 
50. Key features of this approach are:

- As in the plain vanilla and open-economy approaches, the coefficient on the inflation objective, $\delta$, must be high enough to ensure that inflation will be brought back to target over the medium-term; and

- In principle, this approach could be implemented directly through unsterilized intervention in the foreign exchange market. Alternatively, the central bank could use a very short-term domestic interest rate to move the exchange rate to the desired level. ${ }^{36}$

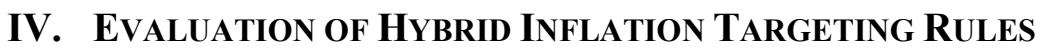

51. In this section, the performance of alternative hybrid IT policy rules in handling domestic demand, cost-push, and risk premium shocks is evaluated using the calibrated models of the financially-robust advanced economy and financially-vulnerable emerging economy. The analysis focuses on three issues:

- Whether hybrid policy rules can outperform plain vanilla IT;

- How much weight, if any, to place on the exchange rate in the policy rule; and

- How hybrid policy rules affect the variability of a wider range of macroeconomic and financial variables.

\section{Hybrid policy rules and the inflation-output volatility trade-off}

52. Figure 1 shows policy tradeoffs for plain vanilla IT in robust advanced and vulnerable emerging economies when exposed to demand, cost-push, and risk premium shocks. The curves, or frontiers, show the combinations of minimum inflation and output variability achievable by varying the weights on inflation and output in the plain vanilla IT policy

rule. ${ }^{37}$ The derivation of the policy trade-off frontiers is explained in Appendix III.

\footnotetext{
${ }^{36}$ In the latter case, the exchange rate can be described as a proximate or operational target, intermediate between the operating instrument and the inflation objective.

${ }^{37}$ Appendix III explains in detail the derivation of the policy trade-off frontiers, and also discusses impulse responses for each type of shock in the two economies.
} 


\section{Figure 1. Plain Vanilla Inflation Targeting in the Robust Advanced Economy and the Vulnerable Emerging Economy}

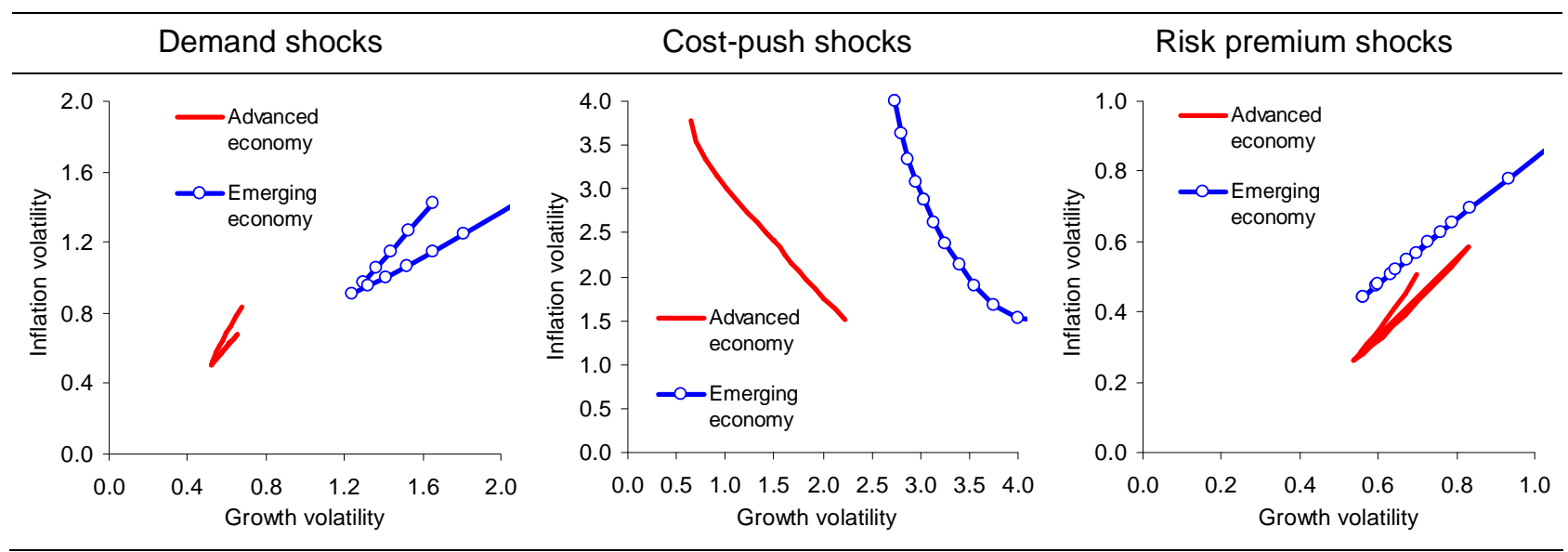

Source: Author's calculations.

53. The charts show that:

- The volatility of output and/or inflation is typically significantly higher in the vulnerable emerging market economy than in the robust advanced economy, for comparably sized shocks of all kinds, reflecting differences in economic structure. ${ }^{38}$

- In both economies the scope for a trade-off between inflation and output variability depends greatly, and broadly similarly, on the nature of the economic disturbances:

- In the case of demand disturbances, the "V" shaped frontiers indicate that there is very little scope for a trade-off between inflation and output variability following a plain vanilla policy rule. For both economies, more forceful policy responses to either inflation or the output gap or both, reduce the volatility of both inflation and output.

- In contrast, with cost-push disturbances, the inflation and output objectives conflict. As a result, there is a clear trade-off between output and inflation variability, which is reflected in the downward sloping frontiers.

- With risk premium disturbances, as with demand disturbances, there is essentially no trade-off between minimizing inflation volatility and output volatility with the plain vanilla policy rule.

54. Figure 2 compares the performances of alternative policy reaction functions in the robust advanced and vulnerable emerging economies. These include: (i) the plain vanilla

\footnotetext{
${ }^{38}$ In particular, the ability of the central bank in the emerging economy to achieve low inflation and output volatility is hindered by the weakness of the interest rate channel of transmission, the perverse exchange rate channel, less forward-looking behavior of private agents, and weaker policy credibility.
} 
rule; (ii) the open economy policy rule with a weight of 0.25 on the change in the exchange rate; (iii) the open economy rule with a weight of 0.25 on a " $1 / 2$ and $1 / 2$ " mix of the change and level of the exchange rate; ${ }^{39}$ and (iv) the exchange rate-based rule, with a weight of 0.7 placed on smoothing the exchange rate.

55. With regard to demand shocks, it is still the case that there is little scope for a tradeoff between output and inflation volatility. However, different policy rules have significant effects on the position of the policy frontier. In the case of the advanced economy, the plain vanilla rule, and the two open economy rules perform very similarly, reflecting the low weight placed on the exchange rate in the calibration of the rule. However, the exchange rate-based rule performs poorly because it significantly dampens appropriate movements in both the exchange rate and the interest rate.

56. In the emerging economy, in contrast, the hybrid rules and especially the exchange rate-based rule lead to lower output volatility, with no greater inflation volatility than under the plain vanilla rule. This result reflects that fact that in the vulnerable economy, the domestic demand shock leads to currency depreciation rather than appreciation, with counterproductive effects on inflation and output volatility. ${ }^{40}$ In these circumstances, resisting depreciation is helpful, both because it minimizes exchange rate pass-through to inflation and because it leads to a stronger interest rate response than would otherwise occur.

57. An important point to note in this context is that the source of the demand shock matters for the emerging economy because of the sensitivity of the exchange rate to the trade balance. With the domestic demand shock, the deterioration in the trade balance induces unhelpful depreciation of the currency. ${ }^{41}$ However, if the demand shock were external in origin, a stronger trade balance would induce helpful currency appreciation. In this case, as in the advanced economy, exchange rate smoothing may be unhelpful.

58. In the event of cost-push disturbances, all of the rules perform very similarly in both types of economy. Adding an element of exchange rate smoothing does not significantly alter the basic conflict that is generated between offsetting the inflation and output effects of such shocks. In both economies, a cost-push shock tends to induce real appreciation of the currency. Resisting this appreciation by cutting interest rates would tend to counter the fall in output, but at the cost of higher inflation. As a consequence, the hybrid rules will tend to shift the policy frontier in the direction of lower output volatility and higher inflation volatility, but, as shown in Figure 2, no closer to the origin.

\footnotetext{
${ }^{39}$ i.e., $\eta=0.5$ in equation $18 \mathrm{~b}$.

${ }^{40}$ See the discussion of impulse responses in Appendix III.

${ }^{41}$ See Appendix III.
} 

Figure 2. Alternative Hybrid Policy Rules and the Variability of Inflation and Output in
Advanced and Emerging Market Economies ${ }^{1 /}$

Financially Robust Advanced Economy

Financially Vulnerable Emerging Economy
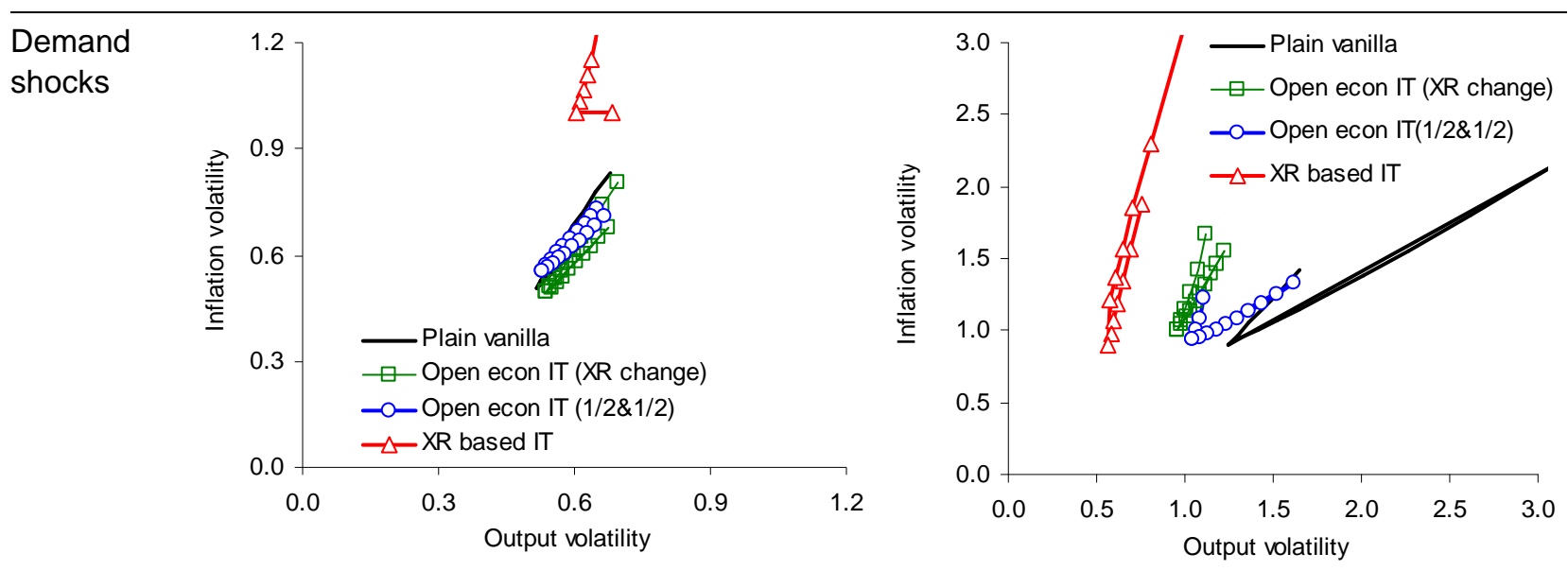

Cost push shocks
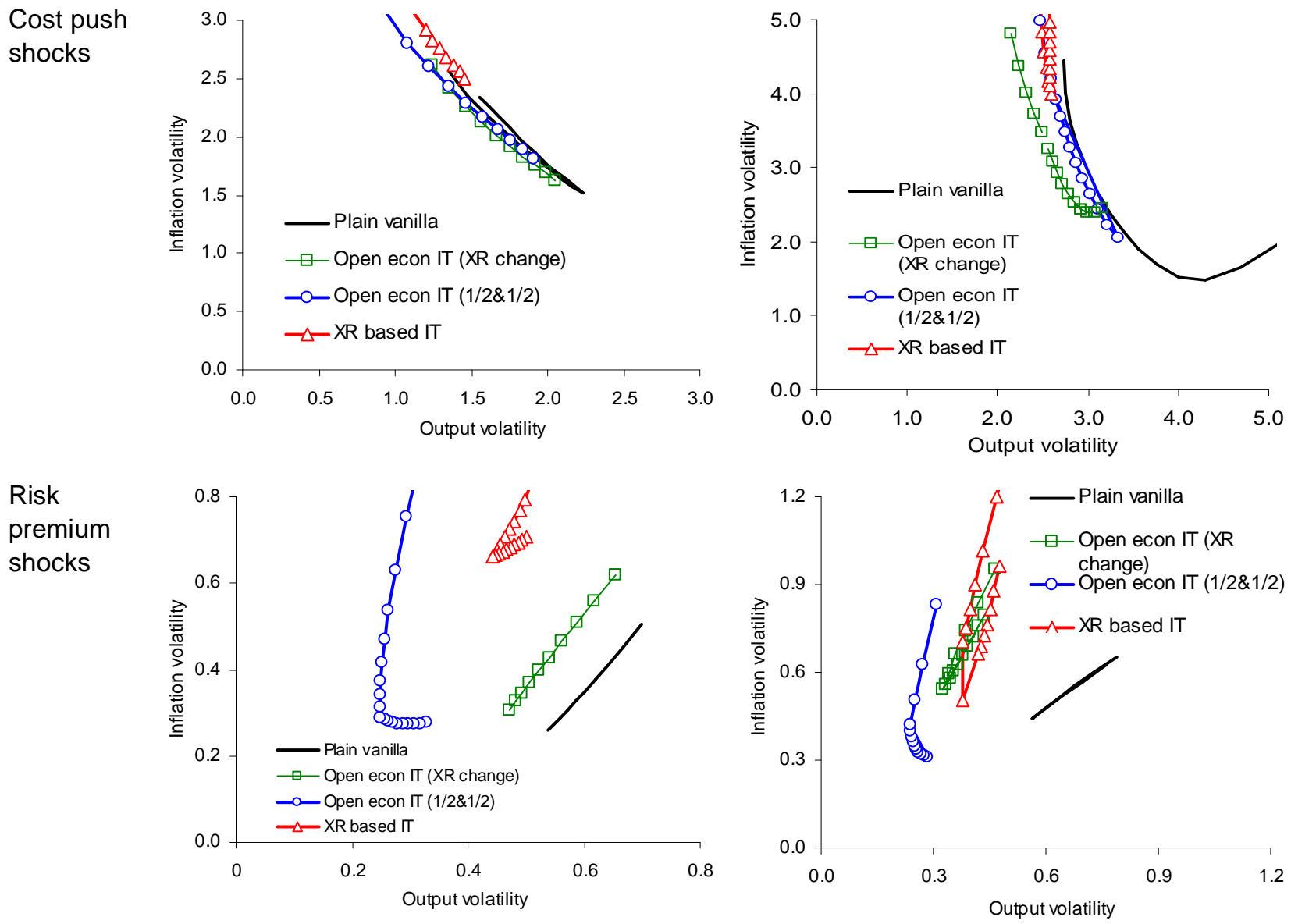

1/ Frontiers are derived by varying the weights on inflation and output gaps in the policy reaction function, while holding the coefficient on the exchange rate objective at 0.25 in the open-economy rules, and the coefficient on instrument smoothing at 0.7 .

Source: Authors' calculations. 
59. With risk premium shocks, the hybrid policy rules tend to outperform the plain vanilla, with the " $1 / 2$ and $1 / 2$ " version of the open economy rule performing particularly well. A risk premium shock leads to a significant currency depreciation in both types of economy, boosting both inflation and output (through increased external competitiveness). Resisting the depreciation tends to reduce the volatility of both inflation and output. An important caveat in this regard, however, is that even though the risk premium shock raises output, consumption falls in both types of economy. Resisting the depreciation of the currency will tend to accentuate the decline in consumption, with the result that a trade-off may arise between dampening inflation and stabilizing domestic demand.

60. These results are generally consistent with conventional views on appropriate policy responses to different kinds of shocks. Ragan (2005) observes that, in an advanced economy, exchange rate movements associated with disturbances directly affecting demand tend to offset the output and inflation effects of the shock. Consequently, rules that dampen exchange rate adjustment to demand disturbances will tend to be counter-productive. If the exchange rate movement is unhelpful, as in may be the case for a domestic demand shock in a vulnerable emerging market, rules resisting the exchange rate movement may be beneficial.

61. In the case of risk premium shocks, the exchange rate movements are destabilizing, so that the hybrid rule including some dampening of exchange rate changes outperforms the plain vanilla approach. This is consistent with Ragan's argument that, in the case of risk premium shocks, an IT oriented monetary policy should aim to offset the induced demand effects of the shock in order to dampen the inflation consequences. This can be achieved by allowing the interest rate to rise just enough to offset the demand stimulus of a weaker currency. ${ }^{42}$ The hybrid rule works in this direction and thus outperforms the plain vanilla approach.

62. The simulation results suggest that for advanced economies, open economy hybrid policy rules with a low weight on the exchange rate, perform very similarly to the plain vanilla rule in handling demand and cost push shocks, and significantly better in handling risk premium shocks. The exchange rate-based policy rule, however, generally performs quite poorly. An exception, as McCallum (2006) observes, may be in an economy that is extremely open. In the emerging economy, the plain vanilla policy rule is generally outperformed by hybrid policy rules. The exchange rate-based approach works well in the event of domestic demand shocks, but not others. The open economy rules perform similarly for demand and cost-push shocks, but the " $1 / 2$ and $1 / 2$ " version works best in the event of risk premium shocks. The reason for this is that this version of the rule induces

\footnotetext{
${ }^{42}$ This is precisely the logic underlying the design and use of a Monetary Conditions Index (MCI), which was to offset the impact of exogenous exchange rate shocks on aggregate demand, with the relative weights in the index reflecting the relative importance of interest rate and exchange rate changes on aggregate demand.
} 
more persistence in the response to the exchange rate movement than the other version, and that this appears to be appropriate in the face of persistent shocks. ${ }^{43}$

63. The choice of policy rule should reflect the predominant kinds of shocks to which the economy is exposed, as well as the structure of the economy. In reality, monetary policymakers are faced with an array of different kinds of shocks, of different magnitudes, often simultaneously. Moreover, there is often substantial uncertainty surrounding the nature of the shocks. In such circumstances, it makes sense for the central bank to have a 'default' rule that is likely to perform reasonably well in response to the kinds of disturbances to which the economy is typically exposed. The analysis in this section suggests that the plain vanilla rule, which performs well in advanced economies primarily affected by demand shocks, may not perform so well as a default rule in many emerging markets.

\section{How much weight to put on the exchange rate in a hybrid policy rule?}

64. Even if it may be beneficial in some circumstances to include the exchange rate in the policy reaction function, a key issue is whether the weight placed on the exchange rate should be large or small. The following simulations focus on how the variability of inflation and output is affected by changing the weight on the exchange rate, while holding fixed the weights placed on the inflation and output objectives. Two cases are considered: In the first, the policy reaction function places high weights on inflation and output. ${ }^{44}$ In the second case, the weights are close to those used in the classic Taylor rule. ${ }^{45}$ The Taylor rule provides a standard benchmark for evaluating modifications to policy rules. An additional consideration is that, as noted in Appendix V, the inflation and output volatility associated with the forceful plain vanilla rule and the Taylor rules are relatively similar in the advanced economy, but quite dissimilar in the vulnerable emerging economy.

65. Figure 3 shows how the variability of inflation and output shifts as the weight on the exchange rate is increased in policy rules with either forceful or Taylor responses to inflation and output. The starting point for each curve is the plain vanilla result, with a weight of zero on the exchange rate. For the advanced economy, the hybrid rule considered is the " $1 / 2$ and $1 / 2$ " open economy rule, which appeared to deliver the best results for hybrid rules in the first set of simulations. For the emerging economy, the " $1 / 2$ and $1 / 2$ " open economy rule is shown, as well as the exchange rate-based IT rule.

\footnotetext{
${ }^{43}$ Wollmershäuser (2006) also finds that a mixed rule outperforms alternatives, even with forward looking expectations. The better performance of this type of rule he attributes to the fact that the both the current and previous values of the exchange rate contain useful forward-looking information that is not being captured in the central bank's incorrect model of the economy.

${ }^{44}$ The weights on inflation and output are 2.4 and 1.6, respectively. Based on the evidence in the literature, these weights are near the limit of what could be considered as practically feasible in reality.
} 
Figure 3. The Impact of Exchange Rate Smoothing on the Variability of Inflation and Output in Robust Advanced and Vulnerable Emerging Economies ${ }^{1 /}$

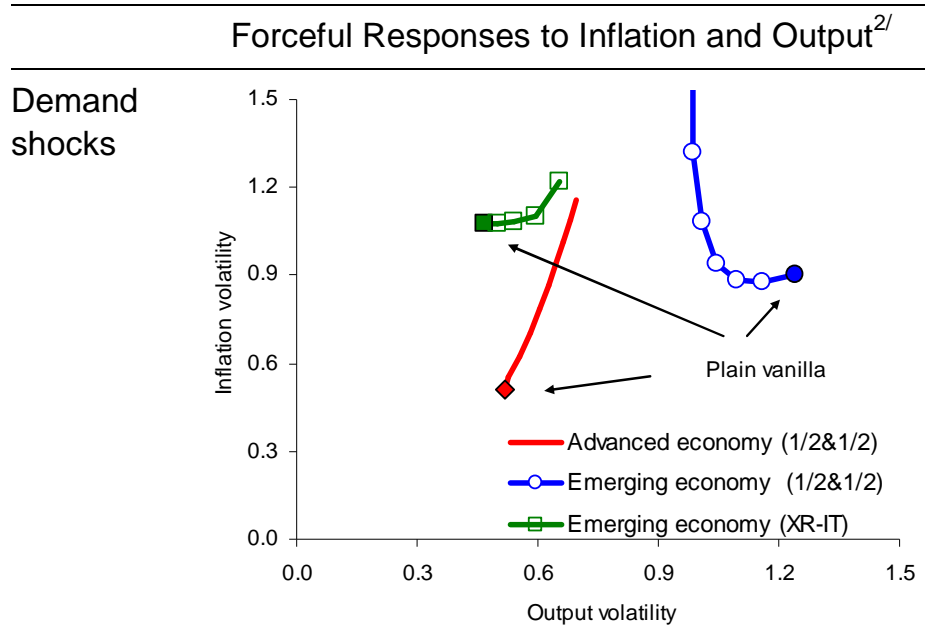

\section{Taylor Responses to Inflation and Output ${ }^{2 /}$}

Cost push shocks
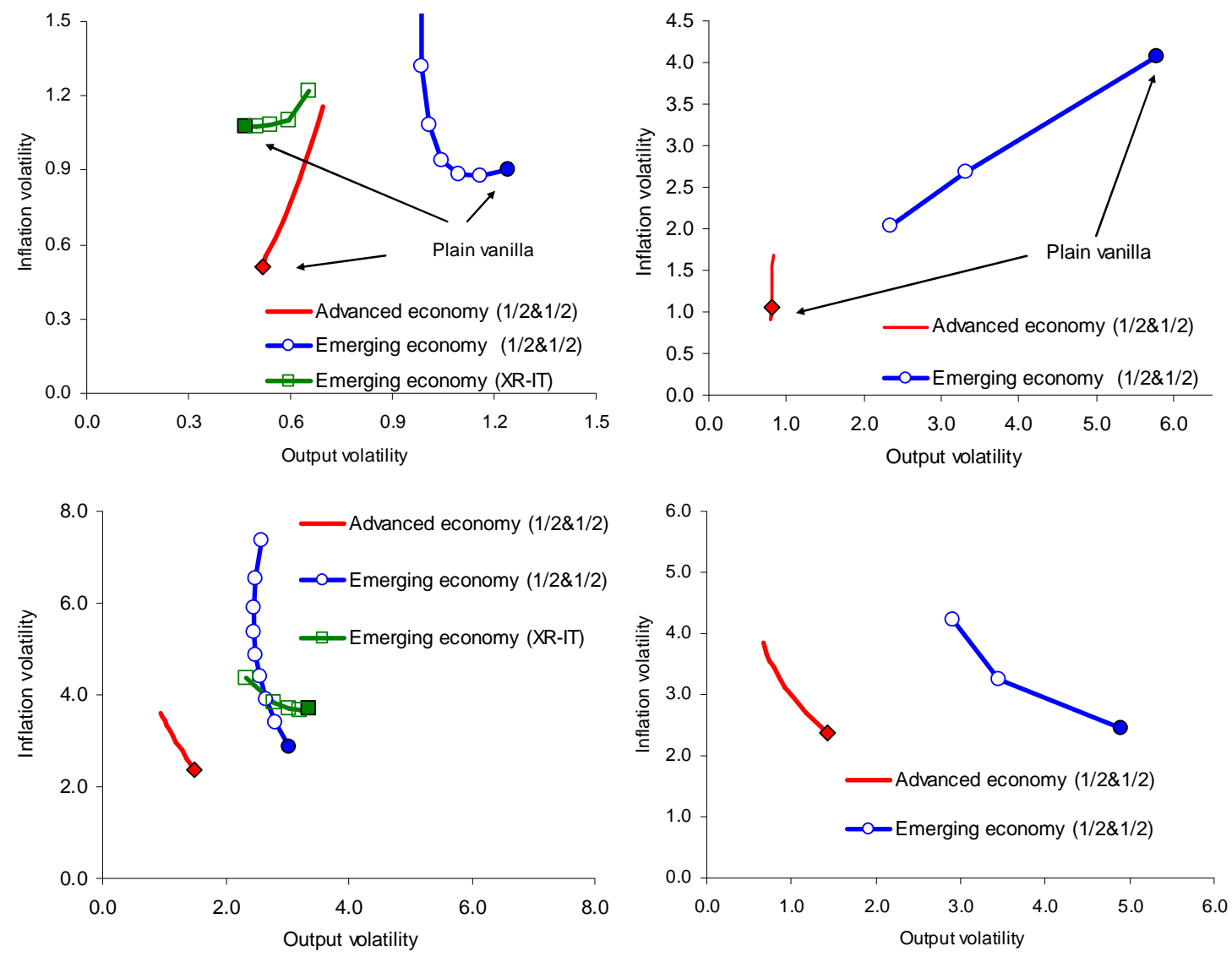

Risk premium shocks
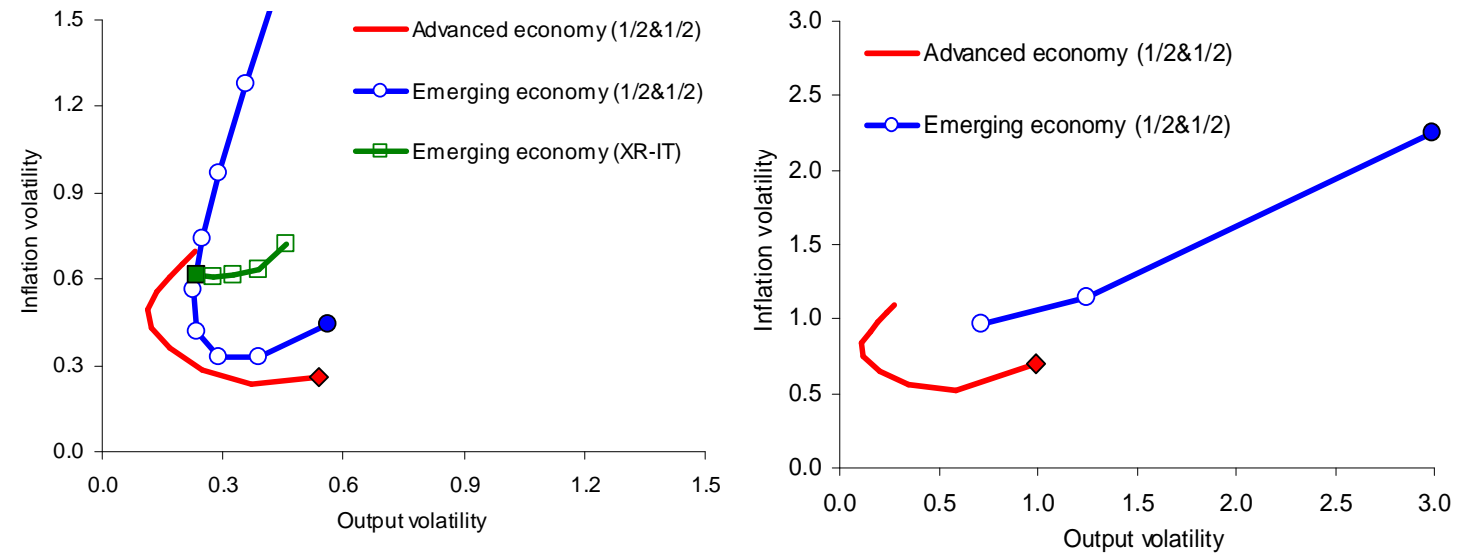

${ }^{45}$ The Taylor rule uses weights of 1.5 and 0.5 on inflation and output, respectively. In the simulations, the weights used are 1.5 and 0.55 . 
1/ Frontiers are derived by varying the coefficient on the exchange rate between zero (plain vanilla IT) and 2.25, while holding the weights on the inflation and output objectives unchanged.

2/ The forceful response puts weights of 2.4 and 1.6 on inflation and output, respectively. The Taylor response puts weights of 1.5 and 0.55 on inflation and output, respectively.

Source: Authors' calculations.

66. The curves in the panels trace out how the inflation/output volatility trade-off shifts as the weight put on the exchange rate in the policy rule increases. In other words, they show whether the trade-off curves in Figure 2 move closer to the origin or further away as the exchange rate smoothing objective increases in importance. In the first panel of Figure 3 , for example, the curve for the advanced economy shows that as the weight on the exchange rate is increased from zero (i.e., a plain vanilla rule), the volatility of output and inflation rises. In the case of the emerging market, increasing the weight on the exchange rate from zero first leads to a decline in output volatility but that increasing the weight beyond about 0.75 mainly serves to increase the volatility of inflation. For exchange ratebased IT in the emerging economy, increasing the degree of exchange rate smoothing raises the volatility of output; and beyond a weight of about 0.75 , raises the volatility of both inflation and output.

67. Overall, the results suggest that, even when it is beneficial to include the exchange rate in the reaction function, the weight placed on it should be quite small:

- $\quad$ For the advanced, financially-robust economy, forceful plain vanilla policy rules perform best in response to demand and cost-push shocks. Including the exchange rate in the policy rule is beneficial for risk premium shocks, but only up to a point -increasing the weight beyond about 1.0 increases volatility of both inflation and output. The results are essentially similar in the policy rule with Taylor responses to inflation and output, although the simulations suggest that placing a small weight (i.e., about 0.25 ) on the exchange rate also slightly reduces inflation volatility in response to demand shocks.

- $\quad$ For the emerging, financially-vulnerable economy, the simulations suggest putting a somewhat higher weight on the exchange rate. With both domestic demand and risk premium shocks, the results suggest that a significant reduction in output volatility can be achieved, with little impact on inflation volatility, by placing a weight of around 0.5 on the exchange rate in the " $1 / 2$ and $1 / 2$ " open economy rule. However, placing any weight on the exchange rate worsens inflation performance in the event of supply shocks.

- In the emerging economy, placing some weight on the exchange rate in a " $1 / 2$ and $1 / 2$ " open economy rule with Taylor responses to inflation and output is especially beneficial. Placing some weight on the exchange rate substantially reduces the volatility of output with all types of shocks, and also reduces inflation volatility in the event of demand and risk premium shocks. Even so, the volatility of inflation and output is still substantially higher than with more forceful responses, so a stronger weight on the exchange rate is not a very good substitute for stronger responses to inflation and output gaps. 


\section{How hybrid policy rules affect a wider range of macroeconomic variables?}

68. Although stable inflation and growth may be the principal concerns of IT central banks, they also typically seek to avoid inducing high variability in interest rates, the exchange rate, and international trade performance. The third set of simulations, therefore, focuses on the impact of alternative hybrid frameworks on the volatility of a wider range of variables than just output and inflation. In these simulations, the weights placed on the inflation, output, and exchange rate objectives are in line with the evidence from the earlier simulations of the combination of weights that would minimize output and inflation volatility. ${ }^{46}$

69. The "cobweb" graphs in Figure 4 plot the variability of output and inflation, real interest rates, the real exchange rate, and the real trade balance associated with domestic demand, cost-push, and risk premium shocks, in advanced and emerging market economies, under alternative IT rules. ${ }^{47}$ The graphs indicate that:

- In general, the volatility of the five variables tends to be greatest in response to costpush shocks. In the advanced economy, overall volatility in response to demand and risk premium shocks is similar, while in the emerging economy volatility is less in response to risk premium shocks than to demand shocks;

- In both types of economy, and for almost all policy rules, the volatility of inflation tends to be higher than for output, and the volatility of the real exchange rate tends to be much higher than for all other variables;

- In the advanced economy, the Taylor rule performs very well in dampening inflation, output and interest rate volatility, but poorly in terms of exchange rate and current account volatility. In the emerging market, however, the Taylor rule performs very poorly compared with alternative rules. Essentially this reflects the fact that in the emerging market economy, where policy transmission is relatively weak, the Taylor rule is insufficiently forceful.

\footnotetext{
${ }^{46}$ See e.g., Taylor (1993), Clarida, Galí, and Gertler (1998 and 2000), and Parrado (2004).

${ }^{47}$ See also Appendix III Tables 3a-c with the data underlying the cobweb graphs. The tables also report results for open economy IT rules based on the level of the exchange rate alone and the change in the exchange rate alone.
} 
Figure 4. Performance of Alternative Policy Rules on Macroeconomic and Financial Volatility in Advanced and Emerging Economies ${ }^{1 /}$

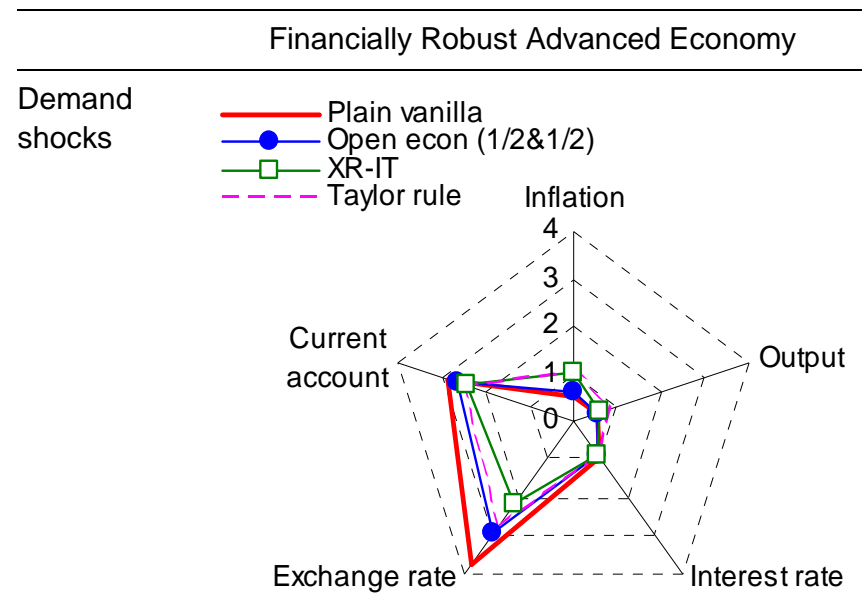

Financially Vulnerable Emerging Economy

Cost push shocks
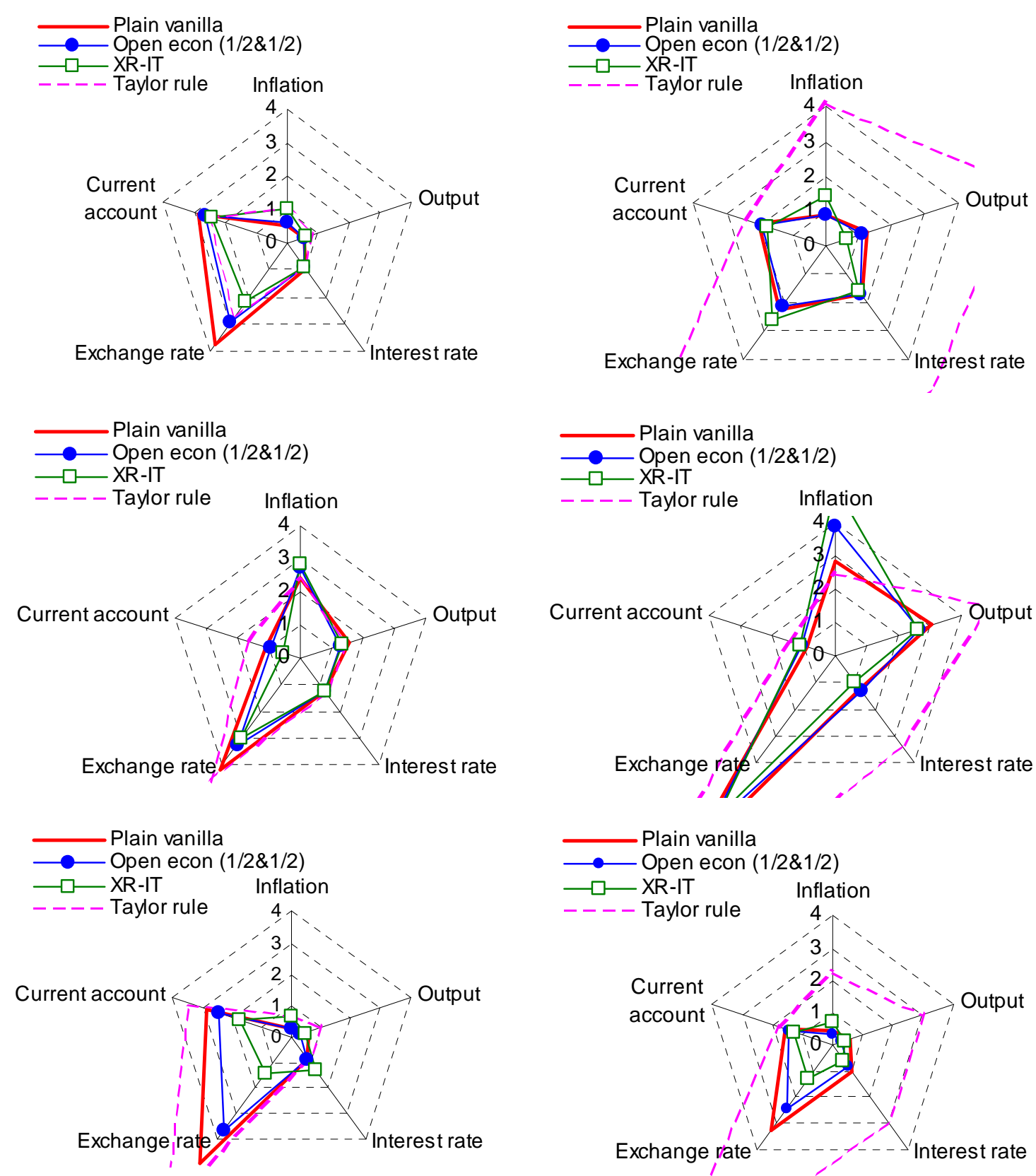
Risk
premium
shocks

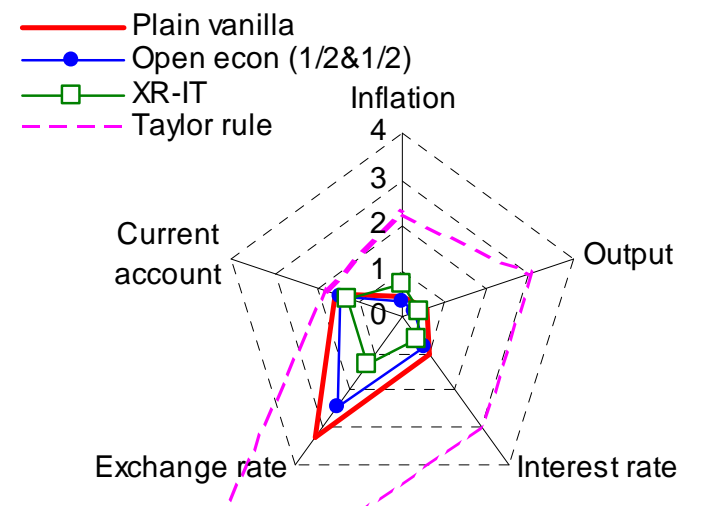

$1 /$ The plain vanilla, open economy (1/2\&1/2), and exchange rate-based rules use weights of 2.4 and 1.6 on inflation and output, respectively. Taylor rule uses weights of 1.5 and 0.55 on inflation and output, respectively. The open economy $(1 / 2 \& 1 / 2)$ rule uses a weight of 0.25 on the exchange rate term, while the exchange rate-based rule uses a weight of 0.7 on the lagged exchange rate.

Source: Authors' calculations. 
70. Table 1, summarizes roughly how the different rules compare in terms of the volatility of inflation and output on the one hand, versus interest rate and exchange rate volatility on the other. The volatilities shown in the table are calculated as the simple average of the standard deviations of the relevant variables, averaged over the three kinds of shocks. The table suggests that for both types of economy, the open economy rule using either the exchange rate change alone, or a $1 / 2$ and $1 / 2$ average of the change and level of the exchange rate could significantly reduce financial volatility compared with a plain vanilla rule, at little if any, cost in terms of output and inflation volatility.

71. Although this result is somewhat sensitive to priority accorded to minimizing the variability of inflation as opposed to output, and to the probabilities and appropriate weighting of different kinds of shocks, the more general point is that having a modest element of exchange rate smoothing in the reaction function may not be very harmful to the primary policy objectives, but may be helpful in reducing volatility in financial markets, especially in financially-vulnerable emerging market economies.

Table 1. Macroeconomic and Financial Volatility Associated with Alternative Policy Rules

\begin{tabular}{|c|c|c|c|c|}
\hline \multirow[b]{2}{*}{ Policy rule } & \multicolumn{2}{|c|}{ Advanced economy } & \multicolumn{2}{|c|}{ Emerging economy } \\
\hline & $\begin{array}{c}\text { Inflation and } \\
\text { output } \\
\text { volatility }^{1 /}\end{array}$ & $\begin{array}{c}\text { Interest rate and } \\
\text { exchange rate } \\
\text { volatility }^{1 /}\end{array}$ & $\begin{array}{c}\text { Inflation and } \\
\text { output } \\
\text { volatility }^{1 /}\end{array}$ & $\begin{array}{l}\text { Interest rate and exchange } \\
\text { rate volatility }{ }^{1 /}\end{array}$ \\
\hline Taylor rule & 1.23 & 2.90 & 3.74 & 7.74 \\
\hline Plain vanilla & 0.96 & 2.65 & 1.51 & 2.87 \\
\hline $\begin{array}{l}\text { Open economy } \\
(1 / 2 \& 1 / 2)\end{array}$ & 0.95 & 2.15 & 1.53 & 2.48 \\
\hline $\begin{array}{l}\text { Open economy } \\
\text { (XR change) }\end{array}$ & 0.95 & 2.42 & 1.46 & 2.66 \\
\hline $\begin{array}{l}\text { Open economy } \\
\text { (XR level) }\end{array}$ & 1.11 & 2.34 & 1.74 & 2.41 \\
\hline XR-based IT & 1.14 & 1.67 & 1.80 & 2.18 \\
\hline
\end{tabular}

1/ Average of standard deviations of variables averaged across demand, cost-push and risk premium shocks Source: Authors' calculations.

\section{General assessment}

72. The simulation results suggest that financially-robust advanced economies have little to lose and potentially some to gain by including the exchange rate directly in the policy reaction function. Consistent with the conventional wisdom, including the exchange rate in the reaction function does little to alter inflation and output performance in the event of demand or cost-push shocks. However, if the economy is vulnerable to risk premium shocks, a hybrid approach outperforms a plain vanilla policy rule. 
73. The results also suggest that financially-vulnerable emerging market economies might benefit from a hybrid IT approach. In such countries, the analysis suggests that a hybrid approach may lead to slightly better output and inflation performance than with a plain vanilla approach. Where the hybrid approach appears to offer more substantial benefits is in reducing volatility in the exchange rate, interest rate, and trade balance, particularly in the event of risk premium disturbances. Since these countries may be much more exposed to such disturbances than financially-robust advanced economies, this is an important advantage.

74. At the same time, the analysis also finds that the weight put on the exchange rate in a hybrid framework should be small relative to the weights on inflation and output. The simulations indicate that putting more than a modest weight on dampening exchange rate volatility is likely to significantly worsen macroeconomic performance. ${ }^{48}$

75. With regard to an exchange rate-based approach to inflation targeting, the analysis suggests that this may work well in lowering volatility of the exchange rate, interest rate, and trade balance, but that this may come at a high price in terms of inflation and output volatility if the economy is particularly exposed to demand and cost-push shocks. As with other hybrid rules, a high degree of exchange rate smoothing in the rule is likely to harm macroeconomic performance. In addition, such a framework may be problematic from an operational perspective. In particular, the framework could be prone to speculative pressures in advance of periodic resets of the exchange rate, resulting in high interest rate volatility, pressure on foreign exchange reserves, or both.

76. For emerging market economies that are in a relatively robust financial position, a hybrid IT framework is likely to be less beneficial than in more vulnerable economies.

Dollarization is fairly low in many emerging market economies, so that the net impact on demand of exchange rate changes is in the same direction as in an advanced economy. ${ }^{49}$ In these circumstances, the case for a hybrid IT approach will tend to be weaker than in a more financially-vulnerable economy. However, such economies may still be more exposed than most advanced economies to risk premium shocks and this is the type of shock where a hybrid approach outperforms plain vanilla IT in both kinds of economy.

\footnotetext{
${ }^{48}$ In the model used in this paper, macroeconomic performance tends to deteriorate significantly if the weight put on exchange rate smoothing is more than about 0.5 . This is consistent with the results in Ravenna and Natalucci (2008), who find that putting a large weight on exchange rate smoothing is disadvantageous in handling sectoral productivity shocks. It may be noted that in their model, the "flexible" exchange rate rule uses a weight on the exchange rate of 0.1 , relative to weights of 0.4 on output and 1.0 on inflation. ${ }^{49}$ See e.g., Tovar (2006) who finds that for the Korean economy, the stimulative effects of devaluation
outweigh balance sheet effects.
} 


\section{Caveats}

77. As with any other small model, the one used in this analysis has important limitations. These constrain the kinds of questions or issues that can be addressed, and also mean that caution is warranted in drawing strong conclusions on the generality of the results. Indeed, the analysis itself points to the need for caution, as the effects of different types of shocks and the implications of differences in economic structure or policy rules can be substantial. Some important issues that are not addressed within the model include:

- The long-run equilibrium, or "steady state," of the economy: In the model used in the analysis, the steady state of the economy is exogenous. Consequently, the model cannot readily compare the performance of alternative policy frameworks in handling changes in the steady state of the economy, nor possible effects of different policy approaches on the steady state. A particular example concerns possible hysteresis effects of real exchange rate movements on potential output, implying that temporary shocks can have permanent effects. It is not clear, however, whether such limitations of the model would, on balance, strengthen the case for whether and how to include the exchange rate in the monetary policy reaction function.

- Uncertainty regarding the steady state: Because the model is specified in terms of deviations of variables from steady-state values, it implicitly assumes that the steady state values are known. Errors in estimating steady state values will result in policy mistakes and greater macroeconomic volatility, than if the steady state values were known. However, it is not obvious that this is an argument for excluding the exchange rate from the reaction function. There has been extensive analysis of an analogous issue - the implications of misestimating potential output. In general, however, research on this issue indicates that even if potential output is mis-estimated, it is still better to include the output gap in the policy reaction function..$^{50}$ An additional consideration is whether errors in the estimates of the steady state values of the real interest rate, real exchange rate, and output gap are likely to be correlated with one another. In principle, at least, inclusion of the exchange rate in the reaction function might improve policy, if errors in measuring the steady state typically offset errors in measuring steady state values of the other variables.

- Uncertainty regarding the correct model of the economy: Although there is always uncertainty about the correct model of the economy, the problem may be more acute in emerging markets undergoing extensive structural change, and where data availability and quality may be weaker than in more advanced economies. In this case, it is desirable to have policy rules that are robust to model error. In this regard, Wollmershäuser (2006) finds that

\footnotetext{
${ }^{50}$ See e.g., Drew and Hunt (2000), and Ehrmann and Smets (2003).
} 
an open economy IT rule is more robust than a plain vanilla rule to a range of errors in specifying the correct model of the exchange rate. ${ }^{51}$

- $\quad$ Linearity of the model: This is a standard property of most models, but has some important implications for this analysis. In particular, it means that the model cannot take into account threshold effects or asymmetries that may be important in the transmission of financial disturbances or exchange rate movements. It also limits the ability to deal with the implications of uncertainty for the design and choice of policy framework. In particular, the model is not really able to address the consequences for different policy rules of uncertainties regarding different shocks or the steady state of the economy.

- $\quad$ Model parameters: The model parameters are imposed rather than estimated. Although most parameters are drawn from the relevant literature, the two country models are deliberately intended to highlight differences. Thus, the emerging market model is calibrated to ensure financial vulnerability. In view of this, the findings of the analysis should not be seen as prescriptions for policy in any particular country. To translate the analysis into policy, the kinds of policy rules examined in this analysis would need to be adapted to models estimated or calibrated to reflect the structure of specific economies.

\footnotetext{
${ }^{51}$ Moreover, the rule which performs best is a mixed rule putting some weight on both the level and change in the exchange rate.
} 


\section{REFERENCES}

Adolfson, M., S. Laséen, J. Lindé, and M. Villani, 2008 "Evaluating an estimated new Keynesian small open economy model" Journal of Economic Dynamics and Control, Volume 32(8), 2690-721.

Aizenman, Joshua, and Michael Hutchison, 2008, "Inflation Targeting and Real Exchange Rates in Emerging Markets,” NBER Working Paper 14561.

Akram, Farooq, and Øyvind Eitrheim, 2008, "Flexible inflation targeting and financial stability: Is it enough to stabilize inflation and output?" Journal of Banking and Finance 32, 1242-54.

Amato, J. and T. Laubach, 2003, "Rule of Thumb Behavior and Monetary Policy," European Economic Review 47, 791-831.

Argov, E., N. Epstein, P. Karam, D. Laxton and D. Rose, 2007, "Endogenous monetary policy credibility in a small macro model of Israel," IMF Working Paper 07/207.

Ball, L., 2000, "Policy Rules and External Shocks," Central Bank of Chile Working Papers 82.

— , 1999, "Policy Rules for Open Economies," in J. Taylor, (ed.), Monetary Policy Rules, (Chicago: University of Chicago Press), 127-144.

Batini, Nicoletta., R. Harrison, and S. Millard, 2001, "Monetary Policy Rules for an Open Economy," Bank of England Working Paper 149.

Batini, Nicoletta, Paul Levine, and Joseph Pearlman, 2007, "Monetary Rules in Emerging Economies with Financial Market Imperfections," Paper presented to the NBER Conference on International Dimensions of Monetary Policy, S'Agaró, Spain, June 11-13, 2007.

Berg, Andrew, Philippe Karam, and Douglas Laxton, 2006, “A practical model-based approach to monetary policy analysis—overview” IMF Working Paper 06/80.

Brook, Anne-Marie, 2002, "The Role of the Exchange Rate in New Zealand's Inflation Targeting Regime," Paper presented at the $14^{\text {th }}$ Pacific Basin Central Bank Conference, Seoul, 2001.

Calvo, G., 1983, "Staggered Prices in a Utility Maximizing Framework," Journal of Monetary Economics 12(3), 383-98.

Cavoli, Tony, 2006. Fear of Floating and Optimal Monetary Policy: with particular reference to East Asia. Queensland University of Technology, Mimeo. 
Cavoli, Tony, and R. Rajan, 2006, "Monetary Policy Rules for Small and Open Developing Economies: A Counterfactual Policy Analysis," Journal of Economic Development 31(1), 89-111.

Céspedes, Luis, Roberto Chang, and Andres Velasco (2004) "Balance Sheets and Exchange Rate Policy” American Economic Review 94(4), 1183-93.

Céspedes, Luis, and Claudio Soto, 2005, "Credibility and Inflation Targeting in an Emerging Market: Lessons from the Chilean Experience," International Finance, 8(3): $545-575$.

Clarida, R., J. Galí, M. Gertler, 1998, "Monetary policy in practice: some international evidence," European Economic Review 42:1033-67.

Clarida, R., J. Galí, M. Gertler, 2000, "Monetary policy rules and macroeconomic stability: evidence and some theory," Quarterly Journal of Economics 64(1): 147-80.

Corsetti, G. and P. Pesenti, 2005, "The simple geometry of transmission and stabilization in closed and open economies," NBER Working Papers 11341.

, 2005, "International dimensions of optimal monetary policy," Journal of Monetary Economics 52(2): 281-305.

Del Negro, M., F. Schorfheide, F. Smets, and R. Wouters, 2005, "On the fit of new Keynesian Models” Journal of Business \& Economic Statistics 25(2):123-62.

Devereux, M.B., and C. Engel, 2003, "Monetary policy in the open economy revisited: price setting and exchange rate flexibility," Review of Economic Studies 70,765-83.

Dong, W., 2007, "Expenditure-Switching Effect and the Choice of Exchange Rate Regime," Bank of Canada Working Paper 2007-54.

Dong, W., 2008, "Do central banks respond to exchange rate movements? Some new evidence from structural estimation," Bank of Canada Working Paper 2008-24.

Drew, Aaron, and Ben Hunt (2000) "Efficient Simple Policy Rules and the Implications of Potential Output Uncertainty," Journal of Economics and Business, 52: 143-160.

Edwards, Sebastian, 2006, "the Relationship Between Exchange Rates and Inflation Targeting Revisited," NBER Working Paper 12163.

Ehrmann, Michael, and Frank Smets (2003) "Uncertain potential output: implications for monetary policy," Journal of Economic Dynamics \& Control, 27: 1611-1638. 
Erceg, Christopher, and Andrew Levin, 2003, "Imperfect credibility and inflation persistence," Journal of Monetary Economics 50, 915-44.

Frommel, M., and F. Schobert, 2006, "Monetary Policy Rules in Central and Eastern Europe," Liebniz Universität Hannover Economics Department Discussion Paper 341.

Galí, J., and T. Monacelli, 2005, "Monetary Policy and Exchange Rate Volatility in a Small Open Economy," Review of Economic Studies, 72, 707-734.

Galí, J., J.D. López-Salido, and J. Vallés, 2004 "Rule-of-Thumb Consumers and the Design of Interest Rate Rules," Journal of Money Credit and Banking, 36(4):739-763.

Galí, J., J.D. López-Salido, and J. Vallés, 2007, "Understanding the Effects of Government Spending on Consumption" Journal of the European Economic Association (5), 227-70.

Gertler, Mark, S. Gilchrist, and F. Natalucci, 2003, "External Constraints on Monetary Policy and the Financial Accelerator," NBER Working Paper 10128.

Kirsanova, T., L. Campbell and S. Wren-Lewis, 2006, "Should Central Banks Target Consumer Prices or the Exchange Rate? The Economic Journal, 208-231.

Lahiri, A., and Carlos Végh, 2001, "Living with the Fear of Floating: An Optimal Policy Perspective," NBER Working Paper 8391.

Laxton, Douglas, and Pesenti Paolo, 2003, "Monetary, Rules for Small, Open, emerging Economies," Journal of Monetary Economics.

Leiderman, Leo., Rodolfo. Maino, and Eric Parrado, 2006, "Inflation Targeting in Dollarized Economies," IMF Working Paper 06/157.

Leitemo, Kai, and Ulf Söderström, 2005, "Simple monetary policy rules and exchange rate uncertainty," Journal of International Money and Finance 24, 481-507.

Mankiw, Gregory, 2000, “The Savers-Spenders Theory of Fiscal Policy Shocks?”, American Economic Review 90, 120-25.

McCallum, Bennett, 2006, "Singapore's Exchange Rate-Centered Monetary Policy Regime and its Relevance for China," MAS Staff Paper 43.

Mishkin, Frederic, 2000, "Inflation Targeting for Emerging Market Countries," American Economic Review 90(2), 105-9. 
Mishkin, Frederic, 2008, "Discussion-Batini, Levine and Pearlman "Monetary Policy Rules in a Partially Dollarized Small Open Economy with Financial Market Imperfections," presented at NBER Conference on International Dimensions of Monetary Policy, S'Agaro, Spain, June 12, 2007.

Mohanty, M., and M. Klau, 2004, "Monetary Policy Rules in Emerging Market Economies: Issues and Evidence," BIS Working Papers 149.

Monacelli, 2004 "Into the Mussa Puzzle Monetary Policy Regimes and the Exchange Rate in a Small Open Economy" Journal of International Economics.

Morón, Eduardo, and Diego Winkelried, 2005, "Monetary Policy Rules for Financially Vulnerable Economies," Journal of Development Economics 76, 25-51.

Parrado, Eric, 2004, “Singapore's Unique Monetary Policy: How Does it Work?” IMF Working Paper 04/10.

Parrado, Eric, 2004, "Inflation Targeting and Exchange Rate Rules in an Open Economy," IMF Working Paper 04/21 (Washington: International Monetary Fund).

Ragan, C., 2005, "The Exchange Rate and Canadian Inflation Targeting," Bank of Canada Working Paper 2005-34.

Ravenna, Federico, and Fabio Natalucci, 2008, "Monetary Policy Choices in Emerging Market Economies: The Case of High Productivity Growth," Journal of Money, Credit and Banking, 40 (2-3): 244-271.

Schmidt-Grohé, S., and M. Uribe, 2003, “Closing Small Open Economy Models” Journal of International Economics 61, 163-185.

Smets, Frank, and Rouf Wouters, 2002, “Openness, Imperfect Exchange Rate Pass-through and Monetary Policy” Journal of Monetary Economics, 49, 947-81.

Smets, Frank and Rouf Wouters, 2007. "Shocks and Frictions in US Business Cycles: A Bayesian DSGE Approach,” American Economic Review 97(3), 586-606.

Stephens, D., 2006, "Should Monetary Policy Attempt to Reduce Exchange Rate Volatility in

New Zealand?” Reserve Bank of New Zealand Discussion Paper 2006/05.

Svensson, Lars, 2000, “Open-Economy Inflation Targeting,” Journal of International Economics 50 (1), 155-83. 
Taylor, John, 1993, "Discretion versus policy rules in practice," Carnegie-Rochester Conference on Public Policy 39:195-214.

Taylor, John, 2001, "The Role of the Exchange Rate in Monetary Policy Rules," American Economic Review 91(2), 263-67.

Tille, Cedric, 2001, "The role of consumption substitutability in the international transmission of monetary shocks," Journal of International Economics 53(2): 421-44.

Tovar, Camilo, 2006, "Devaluations, output and the balance sheet effect: a structural econometric analysis," BIS Working Papers 215.

Truman, Edwin, 2003, Inflation Targeting in the World Economy, (Washington: Institute for International Economics).

Wei, Dong, 2008, "Do Central Banks Respond to Exchange Rate Movements? Some New Evidence from Structural Estimation,” Bank of Canada Working Paper 2008-24.

Wollmershäuser, Timo, 2006, "Should central banks react to exchange rate movements? An analysis of the robustness of simple policy rules under exchange rate uncertainty," Journal of Macroeconomics 28, 493-519. 


\section{APPENDIX I. OPTIMIZATION IN THE MODEL}

\section{Consumer problem}

Households maximize utility from consumption and leisure:

$$
U\left(C_{t}, N_{t}\right)=\frac{\left(C_{t}-\gamma C_{t-1}\right)^{1-\sigma}-1}{1-\sigma}-N_{t}^{v}
$$

subject to a budget constraint:

$$
C_{t}=\frac{W_{t}}{P_{t}} N_{t}+\frac{D_{t}}{P_{t}}+\frac{B_{t+1}^{*}}{\left(1+i_{t}^{*}\right) \phi} \frac{Q_{t}}{Q_{t+1}} \frac{P_{t+1}^{*}}{P_{t}^{*}}-\frac{S_{t}}{P_{t}} B_{t}^{*}+\frac{B_{t+1}}{\left(1+i_{t}\right)} \frac{P_{t+1}}{P_{t}}-\frac{B_{t}}{P_{t}}+\frac{T}{P_{t}}
$$

where:

$C_{t}$ is real consumption in period $t$

$N_{t}$ is labor supply

$W_{t}$ is the nominal wage rate

$P_{t}$ is the domestic price level

$D_{t}$ is dividend income

$B_{t}^{*}$ is foreign debt

$\phi$ is the risk premium

$i_{t}^{*}$ is the foreign interest rate

$Q_{t}$ is the real exchange rate

$P_{t}^{*}$ is the price of imports

$B_{t}$ is domestic assets

$i_{t}$ is the domestic interest rate

$T$ is net transfer income.

That is, nominal Consumption is equal to wage income, WN, plus dividends, $\mathrm{D}$, plus foreign financing or saving measured by the change in the external debt position, $\frac{S_{t} B_{t+1}^{*}}{\left(1+i_{t}^{*}\right) \phi}-S_{t} B_{t}^{*}$, plus domestic financing or saving (debt or assets), $\frac{B_{t+1}}{\left(1+i_{t}\right)}-B_{t}$, plus transfers (or taxes if it is negative) from the government, $T$. Foreign debt is assumed to be denominated in foreign exchange, and is converted to domestic currency terms by 
multiplying by the nominal exchange rate $\mathrm{S}$. In addition, instead of expressing debt growth or assets growth as $S_{t} B_{t+1}^{*}=\left(1+i_{t}^{*}\right) \phi S_{t} B_{t}^{*}$ we divide both sides by $\left(1+i_{t}^{*}\right) \phi .^{52}$

First order conditions of the optimization are:

$C:\left(C_{t}-\gamma C_{t-1}\right)^{-\sigma}=\lambda_{t}$

where $\lambda_{t}$ is the Lagrange multiplier or marginal utility of consumption;

$$
\begin{aligned}
& N: \quad v N_{t}^{v-1}=\lambda_{t} \frac{W_{t}}{p_{t}} \\
& B_{t+1}^{*}: \quad \lambda_{t}=E_{t}\left[\lambda_{t+1} \beta\left(1+i_{t}^{*}\right) \phi \frac{Q_{t+1}}{Q_{t}} \frac{P_{t}^{*}}{P_{t+1}^{*}}\right] \\
& B_{t+1}: \quad \lambda_{t}=E_{t}\left[\lambda_{t+1} \beta\left(1+i_{t}\right) \frac{P_{t+1}}{P_{t}}\right]
\end{aligned}
$$

Solving together (1a) with (4a) the Euler equation is obtained:

$$
\left(C_{t}-\gamma C_{t-1}\right)=E_{t}\left(\left(C_{t+1}-\gamma C_{t}\right)\left[\beta\left(1+i_{t}\right) \frac{P_{t}}{P_{t+1}}\right]^{-1 / \sigma}\right)
$$

Substituting (1a) in (2a) yields the optimized supply of labor:

$$
v N_{t}^{v-1}=\frac{W_{t}}{P_{t}}\left(C_{t}-\gamma C_{t-1}\right)^{-\sigma}
$$

Using equations (1a), (3a), (4a) it is possible to derive the interest parity condition:

$$
E_{t}\left(\frac{Q_{t+1}}{Q_{t}}\left(1+i_{t}^{*}\right) \phi \frac{P_{t}^{*}}{P_{t+1}^{*}}\right)=E_{t}\left(\left(1+i_{t}\right) \frac{P_{t}}{P_{t+1}}\right)
$$

\section{Marginal cost in the case of a CES production function}

Domestic output, $Y_{t}^{d}$, is given by a standard CES production function:

$$
Y_{t}^{d}=A\left[\alpha I_{t}^{\frac{\sigma_{s}-1}{\sigma_{s}}}+(1-\alpha) N_{t}^{\frac{\sigma_{s}-1}{\sigma_{s}}}\right]^{\frac{\sigma_{s}}{\sigma_{s}-1}}
$$

${ }^{52}$ Following Gali and others (2007) 
where:

$A_{t}$ is total factor productivity

$\alpha$ is the share of the imported good in production - the openness of the economy

$I_{t}$ is the imported intermediate input

$\sigma_{s}$ is the elasticity of substitution in production

$N_{t}$ is the labor input

The firm's problem is to choose inputs $N$ and $I$ to minimize its costs

$$
\operatorname{Min} W_{t} N_{t}+S_{t} P_{t}^{*} I_{t}+\eta_{t}\left\{Y^{\frac{\sigma_{s}-1}{\sigma_{s}}}-A\left[\alpha I_{t}^{\frac{\sigma_{s}-1}{\sigma_{s}}}+(1-\alpha) N_{t}^{\frac{\sigma_{s}-1}{\sigma_{s}}}\right]\right\}
$$

where:

$W_{t}$ is the nominal wage rate

$S_{t}$ is the nominal exchange rate

$P_{t}^{*}$ is the price of imports

$\eta_{t}$ is the Lagrange multiplier or marginal cost of production

First order conditions for the optimization are:

$$
\begin{aligned}
& N: \quad W_{t}=\lambda(1-\alpha) \frac{\sigma_{s}-1}{\sigma_{s}} A^{\frac{\sigma_{s}-1}{\sigma_{s}}} N_{t}^{\frac{-1}{\sigma_{s}}} \\
& I: \quad S_{t} P_{t}^{*}=\lambda \alpha \frac{\sigma_{s}-1}{\sigma_{s}} A^{\frac{\sigma_{s}-1}{\sigma_{s}}} I_{t}^{\frac{-1}{\sigma_{s}}}
\end{aligned}
$$

Relative prices are derived from the first order conditions:

$$
\frac{W_{t}}{S_{t} P_{t}^{*}}=\left(\frac{1-\alpha}{\alpha}\right)\left(\frac{I_{t}}{N_{t}}\right)^{\frac{1}{\sigma_{s}}}
$$

And demands for factors of production are given by:

$$
N_{t}=\left(W_{t} / \lambda(1-\alpha) \frac{\sigma_{s}-1}{\sigma_{s}} A^{\frac{\sigma_{s}-1}{\sigma_{s}}}\right)^{-\sigma_{s}} \quad \text { and } \quad I_{t}=\left(S_{t} P_{t}^{*} / \lambda \alpha \frac{\sigma_{s}-1}{\sigma_{s}} A^{\frac{\sigma_{s}-1}{\sigma_{s}}}\right)^{-\sigma_{s}}
$$


After some algebra total nominal cost is found:

$$
T C_{t}^{n}=\frac{1}{A_{t}} Y_{t}^{d}\left[\alpha^{\sigma_{s}}\left(S_{t} P_{t}^{*}\right)^{1-\sigma_{s}}+(1-\alpha)^{\sigma_{s}}(W)^{1-\sigma_{s}}\right]^{\frac{1}{1-\sigma_{s}}}
$$

And nominal marginal cost corresponds to:

$$
M C_{t}^{n}=\frac{1}{A_{t}}\left[\alpha^{\sigma_{s}}\left(S_{t} P_{t}^{*}\right)^{1-\sigma_{s}}+(1-\alpha)^{\sigma_{s}}(W)^{1-\sigma_{s}}\right]^{\frac{1}{1-\sigma_{s}}}
$$

Real marginal cost is obtained in terms of real wage and real exchange rate, dividing the price of each input by the price level, $P_{t}$ :

$$
M C_{t}^{r}=\frac{1}{A_{t}}\left[\alpha^{\sigma_{s}}\left(Q_{t}\right)^{1-\sigma_{s}}+(1-\alpha)^{\sigma_{s}}\left(W_{t} / P_{t}\right)^{1-\sigma_{s}}\right]^{\frac{1}{1-\sigma_{s}}}
$$

The log-linearized version of this expression should be included in the Phillips curve.

\section{Phillips curve}

The problem of the firm is to maximize expected profits:

$E_{t} \sum_{k=0}^{\infty}(\beta \theta)^{k}\left[P_{t}^{*}-M C_{t+k}^{n}\right] y_{t+k}^{d}(z)$

Where:

$\beta$ is the subjective rate of time preference

$\theta$ is the fraction of periods in the year that prices are not adjusted

$Y_{t+k}^{d}(z)$ is the expected production of each firm, $z$, between period $t$ and $t+k$

$M C_{t+k}^{n}$ is the expected nominal marginal cost of production between $t$ and $t+k$

Subject to the constraint that supply equals demand:

$Y_{t+k}^{d}(z)=\left(\frac{P_{t+k}}{P_{t}^{*}}\right)^{\varepsilon} Y_{t+k}^{d}$

Where:

$Y_{t+k}^{d}$ is total domestic production between $t$ and $t+k$ 
Demand for an individual firm's output depends on the relative price of its output and total output of the economy. Firms are monopolistic competitors, facing downward sloping demand curves.

The result of the optimization problem is combined with the Calvo type pricing:

$$
P_{t}=\left\{\theta\left[P_{t-1}\left(\frac{P_{t-1}}{P_{t-2}}\right)^{\mu}\right]^{1-\varepsilon}+(1-\theta)\left[P_{t}^{o p t}\right]^{1-\varepsilon}\right\}^{\frac{1}{1-\varepsilon}}
$$

To obtain the aggregate rate of price adjustment:

$\hat{\pi}_{t}=\frac{\beta}{1+\beta \mu} \hat{\pi}_{t+1}+\frac{\mu}{1+\beta \mu} \hat{\pi}_{t-1}+\frac{\varsigma}{1+\beta \mu} \hat{m} c_{r}^{R}$

Where:

$\hat{\pi}_{t}$ is the $\log$ deviation of inflation from the steady state value

$\mu$ is the proportion of prices indexed to past inflation

$\varsigma=\frac{1-\theta}{\theta}(1-\beta \theta)$, where $(1-\theta)$ is the average frequency of price adjustment by optimizing firms

$\hat{m} c_{t}^{R}$ is the log deviation of real marginal cost of production from the steady state value

\section{Export demand}

Demand for exports of the domestically-produced composite good, $X_{t}^{d}$ depends on the real exchange rate, $Q$, and foreign demand, $Y_{t}^{*}$ :

$X_{t}^{d}=\left[\left(\frac{P_{t}}{S_{t} P_{t}^{*}}\right)^{-\tau} Y_{t}^{*}\right]^{\left(1-\rho_{x^{d}}\right)} X_{t-1}^{\rho_{x^{d}}}$ or, equivalently, $X_{t}^{d}=\left[\left(Q_{t}\right)^{\tau} Y_{t}^{*}\right]^{\left(1-\rho_{x^{d}}\right)} X_{t-1}^{\rho_{x^{d}}}$

Where:

$\rho_{x^{d}}$ is the degree of persistence in domestic exports

$\tau$ is the real exchange rate elasticity of demand for domestically-produced exports 


\section{Appendix II. Calibration OF THE Model}

1. The model is calibrated using values taken from different studies or based on some international stylized facts, in particular for emerging economies (see Table 1). The calibrations of the financially-robust and vulnerable economies are different. Given that the focus of the modeling is the analysis of financial vulnerability, such differences are concentrated in four parameters that reflect more precisely financial vulnerability.

2. The discount factor $\beta$ is 0.988 , not far from the values found elsewhere in the literature (0.99), and coherent with an annual real interest rate of 4.8 percent, which is higher than the rate observed in the most advanced economies. The risk aversion coefficient $\sigma$ is 1.5 , within the range commonly used for this parameter in this kind of models. Labor supply elasticity equals 2 , in line with Adolfson et al (2008).

3. In the advanced economy, with a well-developed financial system, it is assumed that all consumers are able to optimize intertemporal consumption. Consequently, the proportion of consumption based solely on current income is assumed to be zero (i.e., $\lambda=0$ ). In contrast, in the financially-vulnerable economy, the proportion of consumption based on current income, $\lambda$, is assumed to be 0.3 , which is close to the values considered in other studies (Mankiw, 2000, and Galí et al, 2007).

4. The other coefficients that reflect vulnerability and help in addressing the main objective of this article, are part of the risk premium included in the uncovered interest parity condition. In the robust economy, the elasticity of the country risk premium to foreign debt is $(0.02)$ while in the financially vulnerable case it is 0.04 . In other words, the vulnerable economy faces a tighter financial restriction since the risk premium reaction to foreign debt is larger. This coefficient supports the stability of the small open economy model, given that it forces the current account, as well as net foreign assets, to be stationary. The elasticity of the country risk premium to exports and imports are 0.10 , and 0.15 respectively. Finally, the risk premium elasticity to the real exchange rate (balance sheet effect) is 0.19 . It is important to point out that these coefficients are zero in the robust economy, therefore, they are at the core of the main results. Finally, the uncovered interest parity condition has inertia, as in Adolfson et al (2008) and Berg et al (2006).

5. The price elasticity of demand for domestically-produced goods is 6 , yielding a mark-up of 20 percent. Regarding price setting, 70 percent of firms in the advanced economy are assumed to follow forward-looking price optimization, while only 40 percent of firms in the emerging market do so. Among the optimizing firms in both economies, it is assumed that firms normally adjust prices once per year, so that the fraction of firms that keep their prices unchanged each period is 0.75 . The remaining 30 percent of firms in the advanced economy, and 60 percent of firms in the emerging market, that do not follow forward-looking price optimizations, are assumed to index their prices to recent inflation. These shares are in line with the priors of Adolfson et al (2008) and Smets and Wouters (2006). 
6. Since imported goods are production inputs, we assume for simplicity that the elasticity of substitution between labor and imported goods is unity. Furthermore, we choose values close to 0.25 to define the share of imports in the production function, which also defines the degree of openness. Indeed, it implies a ratio of imports to GDP of 0.3. This ratio is common among small open economies, both emerging and developed.

7. The elasticity of domestic exports to the real exchange rate is 5 , given the strong competition small open economies face. In fact, it is possible to argue that domestic exporters face a similar elasticity to what is used in models for developed economies in the case of intermediate goods (Galí and Monacelli, 2005, Galí et al, 2007, Del Negro et al, 2005).

8. The size of the coefficient in the monetary rule with respect to inflation, $\delta$, ranges from 1.05 to 2.4 , and the coefficient with respect to output, $\varphi$, ranges from 0.25 to 1.6. Finally, the weight of the exchange rate, $\chi$, ranges from 0 to 2.25. These intervals include standard values for the Taylor rule (Taylor, 1993). In addition, these levels are considered feasible for central banks according to international evidence (Clarida, Galí, and Gertler, 1998, 2000; Parrado, 2004). Higher coefficients could perhaps generate frontiers closer to the origin but are not considered to be in the feasible range.

9. With regard to monetary policy credibility, it is assumed that policy is highly credible in the advanced economy, so that there is no bias in the formation of inflation expectations. In the emerging economy, however, a bias is assumed. Movements in actual inflation are assumed to feed strongly into revisions of the perceived inflation target, reflected in the value of 2 for the coefficient $\kappa$, and have a persistent effect reflected in the value of 0.8 for the persistence coefficient, $\rho_{p}$. The feed-through of the perceived inflation bias into expectations, however, is assumed to be limited, as reflected in the policy credibility coefficient of $\psi$ set at 0.1 .

10. In steady state, the model features a foreign debt to GDP ratio of 40 percent; commodity production amounts to 12 percent of GDP, and imports amount to 30 percent. The autoregressive coefficient of demand and risk premium shocks $(\rho)$ is 0.8 ; in the case of cost-push shocks we used 0.6.

11. For the sake of comparability all shocks have the same size (1.0) and persistence (0.8). 


\section{Table 1. Parameter Calibration of the Advanced and Emerging Market Economy Models}

\begin{tabular}{|c|c|c|}
\hline Parameters & Advanced economy & Emerging market \\
\hline \multicolumn{3}{|l|}{ Utility function } \\
\hline Subjective discount rate: $\beta$ & 0.988 & 0.988 \\
\hline Coefficient of relative risk aversion: $\sigma$ & 1.50 & 1.50 \\
\hline Parameter of the labor supply (disutility): $v$ & 2.00 & 2.00 \\
\hline Habit coefficient: $\gamma$ & 0.00 & 0.00 \\
\hline $\begin{array}{l}\text { Share of rule of thumb consumers: } \lambda \\
\text { Production function }\end{array}$ & 0.00 & 0.30 \\
\hline Factor (input) elasticity of substitution in production function: $\sigma_{s}$ & 1.00 & 1.00 \\
\hline $\begin{array}{l}\text { Weight of imported factor (degree of openness): } \alpha \\
\text { Exports }\end{array}$ & 0.25 & 0.25 \\
\hline Export persistence for home goods: $\rho_{x^{d}}$ & 0.00 & 0.00 \\
\hline Elasticity of home exports to exchange rate: $\tau$ & 5.00 & 5.00 \\
\hline Elasticity of commodity exports to exchange rate & 0.00 & 0.00 \\
\hline \multicolumn{3}{|l|}{ Price setting } \\
\hline Probability of not re-optimizing: $\theta$ & 0.75 & 0.75 \\
\hline Degree of indexation (for firms that are not re-optimizing): $\mu$ & 0.30 & 0.60 \\
\hline Coefficient on expected inflation: $\beta /(1+\beta \mu)$ & 0.76 & 0.62 \\
\hline Coefficient on lagged inflation: $\mu /(1+\beta \mu)$ & 0.23 & 0.38 \\
\hline Coefficient on marginal cost:: $\varsigma /(1+\beta \mu)$ & 0.07 & 0.05 \\
\hline $\begin{array}{l}\text { Price elasticity of demand: } \mathcal{E} \\
\text { Parity condition } \& \text { risk premium }\end{array}$ & 6.00 & 6.00 \\
\hline Persistence in the real exchange rate: $\phi^{s}$ & 0.60 & 0.60 \\
\hline Elasticity of country risk premium to foreign debt: $\phi_{0}$ & 0.02 & 0.04 \\
\hline Elasticity of country risk premium to exports: $\phi_{1}$ & 0.00 & 0.10 \\
\hline Elasticity of country risk premium to imports: $\phi_{2}$ & 0.00 & 0.15 \\
\hline Elasticity of risk premium to real exchange rate (balance sheet ): $\phi_{3}$ & 0.00 & 0.19 \\
\hline \multicolumn{3}{|l|}{ Monetary policy } \\
\hline Interest rate smoothing in Taylor rule: $\rho_{i}$ & 0.70 & 0.70 \\
\hline Exchange rate smoothing in exchange rate-based inflation targeting: $\rho_{q}$ & 0.70 & 0.70 \\
\hline Coefficient on inflation gap: $\delta$ & $1.05 \leq$ coeff. $\leq 2.40$ & $1.05 \leq$ coeff. $\leq 2.40$ \\
\hline Coefficient on output gap: $\varphi$ & $0.25 \leq$ coeff. $\leq 1.60$ & $0.25 \leq$ coeff. $\leq 1.60$ \\
\hline Coefficient on exchange rate: $\chi$ & $0.00 \leq$ coeff. $\leq 2.25$ & $0.00 \leq$ coeff. $\leq 2.25$ \\
\hline $\begin{array}{l}\text { Monetary policy credibility } \\
\text { Influence of credibility in expectations formation: } \psi\end{array}$ & 0.00 & 0.10 \\
\hline Persistence of target expectation: $\rho_{p}$ & .. & 0.80 \\
\hline $\begin{array}{l}\text { Coefficient on deviation of inflation from target: } \kappa \\
\text { Shock Inertia }\end{array}$ & .. & 2.00 \\
\hline Shock persistence* & Rho_R $=0.80$ & Rho_R $=0.80$ \\
\hline
\end{tabular}

* In the case of the cost-push shock, persistence is 0.6.

Source: Authors' calculations. 


\section{APPENDIX III. SIMULATIONS}

12. This appendix describes the simulation methods used to construct the policy frontiers, and describes the impulse responses of the models in response to different shocks. In addition, the appendix reports the standard deviations of macroeconomic variables under alternative policy rules.

\section{A. Construction of Volatility Trade-off Frontiers}

\section{Shock simulations}

13. The volatility trade-off frontiers shown in the main text are constructed as follows:

- $\quad$ The two types of country models were simulated with 1000 variants of each alternative policy reaction function. The variants of policy rules were constructed with all possible combinations of ten different weights on the inflation and output objectives, respectively, as well as on the exchange rate as shown in Table 2, below. These coefficients are considered feasible according to selected empirical evidence of estimated central bank policy reaction functions (Taylor, 1993; Clarida et al, 1998 and 2000, Parrado, 2004). The coefficient on the lagged instrument term was held constant.

Table 2. Reaction Function Coefficients

\begin{tabular}{cccc}
\hline & Inflation & Output & \multicolumn{2}{c}{ Real exchange rate } \\
& $\delta$ & $\varphi$ & $\chi$ \\
\hline 1 & 1.05 & 0.25 & 0.00 \\
2 & 1.20 & 0.40 & 0.25 \\
3 & 1.35 & 0.55 & 0.50 \\
4 & 1.50 & 0.70 & 0.75 \\
5 & 1.65 & 0.85 & 1.00 \\
6 & 1.80 & 1.00 & 1.25 \\
7 & 1.95 & 1.15 & 1.50 \\
8 & 2.10 & 1.30 & 1.75 \\
9 & 2.25 & 1.45 & 2.00 \\
10 & 2.40 & 1.60 & 2.25 \\
\hline
\end{tabular}

Source: Authors' calculations.

- $\quad$ Each country model, with each variation of the parameterization of the alternative policy rules, is then simulated in response to each of three kinds of shocks: demand, costpush, and risk premium shocks. 
- $\quad$ Each simulation involves a 200 period run. In each period the model is subjected to a shock drawn from a normal distribution. ${ }^{53}$ For each kind of shock, the 200 period simulation is replicated 40 times. $^{54}$

- These simulations provide ten time series with 200 observations, for each kind of shock and each policy rule variant, for each of the 29 endogenous variables. Of these, the variables of most interest are inflation, output, the interest rate, the exchange rate, and the trade balance. The standard deviation of the time series for each variable is then computed, between the $100^{\text {th }}$ and $120^{\text {th }}$ observation, and then averaged over each of the 40 replications, to come up with a standard deviation for each variable in response to each kind of shock and policy variant. ${ }^{55}$

14. In this analysis, the perspective taken is that inflation and output smoothing are the ultimate objectives of monetary policy, whereas smoothing of the policy instrument or the exchange rate are to be evaluated in terms of their performance in achieving the foremost policy objectives.

\section{Frontiers}

15. Once the simulations are performed, the results are organized by shocks, rules, and the coefficient on the exchange rate. For each of the 100 variants of coefficients on output and inflation in the policy rules, the averaged values of the standard deviations of inflation and output obtained in the shock simulations are then used to generate a scattergram of output and inflation volatility outcomes. The outer edges of the scattered points are then used to construct an "envelope" representing the minimum volatility of inflation, for any given level of output volatility, and vice versa, for the particular policy rule.

16. Figure 1 shows two scattergrams: the first for the advanced economy and the second for the emerging market. The scattergrams represent the possible combinations of output and inflation volatility when the economies are hit by demand shocks, and use a plain vanilla monetary policy rule. The different points correspond to different weights put on inflation, $\delta$, and output, $\varphi$, as in Table 2. The envelopes containing these points are shown in the first panel of Figure 1 in the main text.

\footnotetext{
${ }^{53}$ The shocks have a mean of zero and a standard deviation of one. Thus, the shock could be interpreted as a one percent shock with the responses of the variables being percentage deviations from steady state (Galí, 2003).

${ }^{54}$ Each simulation run uses a different initial seed for the random number generation, so that each run is genuinely different. The same set of seeds, however, are used for each kind of shock to ensure that differences in results for the different kinds of shocks are not attributable to the particular random draws.

55 The selection of the $100^{\text {th }}$ to $120^{\text {th }}$ observations is basically to ensure that the observations in the sample are dominated by cross-sectional rather than longitudinal variation, and also free from the influence of initial conditions.
} 
Figure 1. Inflation and Output Volatility With Demand Shocks and Plain Vanilla Inflation Targeting
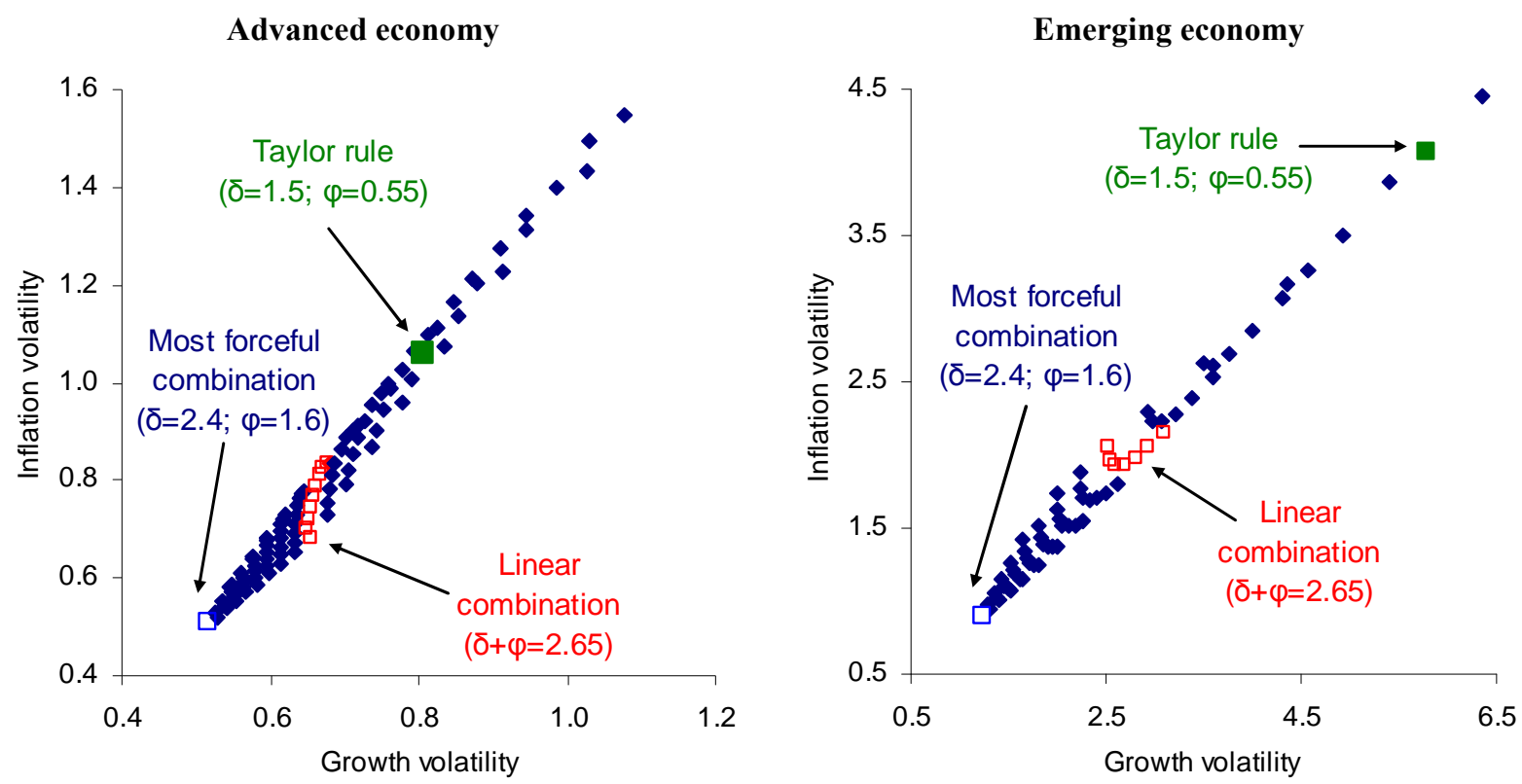

Source: Authors' calculations.

17. A number of features of the two scattergrams can be noted:

- $\quad$ More forceful policy reaction functions tend to result in less volatile output and inflation in the case of demand shocks. For both kinds of economy, policy rules with higher summed weights on inflation and output tend to generate output and inflation volatility combinations closer to the origin. As a result, the combination closest to the origin is with a weight of 2.4 on inflation and 1.6 on output.

- In the emerging economy, under the most forceful policy combination, output and inflation volatility is roughly double that in the advanced economy using the same rule. This largely reflects differences in the efficiency of interest rate and exchange rate transmission in two economies.

- A striking result is the difference in performance of a standard Taylor rule (Taylor 1993) in the two economies. In the advanced economy, the Taylor rule generates output and inflation volatility roughly double that under the most forceful rule (i.e., comparable to the best possible result in the emerging economy); while in the emerging economy, the Taylor rule generates inflation and output volatility roughly four times as great as under the most forceful rule.

- $\quad$ For any given degree of overall policy forcefulness, the trade-offs faced by the advanced and emerging market differ slightly. For illustrative purposes, the figure compares outcomes in the two economies using a policy rule in which the weights on output and 
inflation sum to $2.65 .{ }^{56}$ In the advanced economy, it can be seen that the rule generates a nearly flat set of outcomes. In these circumstances, the best rule will be the one that puts little weight on output and most weight on inflation. In the case of the emerging economy, however, the outcomes, using the same rule, are convex to the origin, indicating more of a trade-off. In this case, the rule which minimizes the variability of both output and inflation puts a weight of 1.6 on inflation and 0.85 on output.

\section{B. Impulse Responses}

18. The two model economies are hit with three different shocks: demand, risk premium, and cost-push. In all cases, it is assumed that the central bank implements the forceful version of plain vanilla inflation targeting (i.e., with weights of 2.4 and 1.6 on inflation and output, respectively). In general, responses behave well in the sense that variables move according to economic intuition. Also, inflation and output are more volatile in the financially-vulnerable economy than in the robust one.

\section{Domestic demand shocks}

19. With a positive domestic demand shock, consumption, domestic GDP, and imports grow in the financially robust advanced economy (Figure 2). Excess demand also puts upward pressure on inflation. In response to the positive output gap and higher inflation, the central bank raises real interest rates, which also leads to real appreciation of the home currency. The trade balance deteriorates in response to the rise in consumption relative to output and the loss of competitiveness. The exchange rate plays a key role in restoring equilibrium, both through its effect on dampening demand pressures, and via direct passthrough effects on traded goods prices.

20. In the financially-vulnerable emerging economy, the demand shock also stimulates consumption and imports. However, there are two important differences with the advanced economy. First, in the emerging economy, the stimulus to consumption is greater than in the advanced economy (largely reflecting the higher proportion of consumption out of current income than in the advanced economy) and this puts greater upward pressure on inflation.

21. Second, in contrast with the advanced economy, the currency depreciates as the upward pressure on the currency from higher interest rates is more than offset by the impact of a rising risk premium associated with the deterioration in the trade balance and net foreign debt position, as well as the adverse impact of depreciation on balance sheets. As a result, upward pressure on interest rates is accentuated at the same time as the currency depreciates. The depreciation tends to accentuate the rise in inflation directly via passthrough effects, as well as indirectly, by adding to the demand stimulus through greater export competitiveness. In these circumstances, monetary policy has to work harder, through a more sustained increase in real interest rates, to dampen demand and bring inflation back toward the target. In the process, the currency appreciates, reinforcing the

\footnotetext{
${ }^{56}$ This is similar to the combined weight of 2.8 for the coefficients used in the policy rules in Stone and others (2009).
} 
effects of higher interest rates. In contrast with the advanced economy, therefore, the initial response of the exchange rate to the shock is unhelpful, making the task for monetary policy more difficult than otherwise.

Figure 2. Responses to a Demand Shock
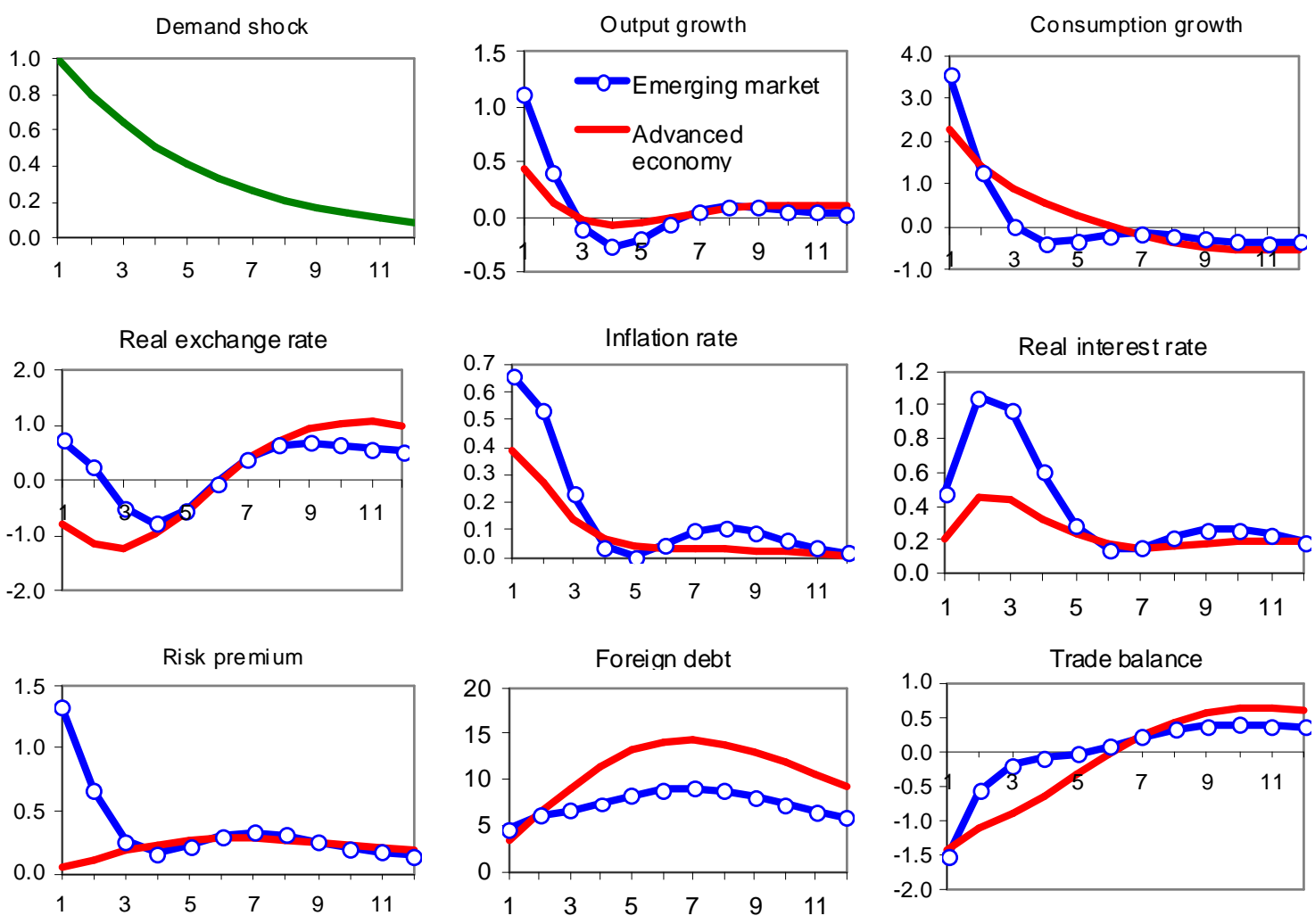

Source: Authors' calculations.

\section{Cost-push shocks}

22. In both the advanced and emerging economies, this type of shock leads demand and output to fall at the same time as inflation rises, resulting in conflicting objectives for monetary policy (Figure 3). Additionally, in both economies, the initial rise in inflation results in real appreciation of the currency, which is reinforced by an increase in real interest rates. However, as in the case of a demand shock, there are important differences in the dynamics of adjustment in the two economies.

23. In the advanced economy, forward-looking consumption falls immediately - and by more than output-leading to an external trade surplus. Subsequently, monetary tightening to counter the rise in inflation raises real interest rates, contributing to some further appreciation and deterioration in the external balance. Gradually, as the adverse shock unwinds, output returns toward potential and inflation falls, allowing interest rates to fall. In the process, the initial appreciation of the currency is reversed. 
Figure 3. Responses to a Cost-push Shock
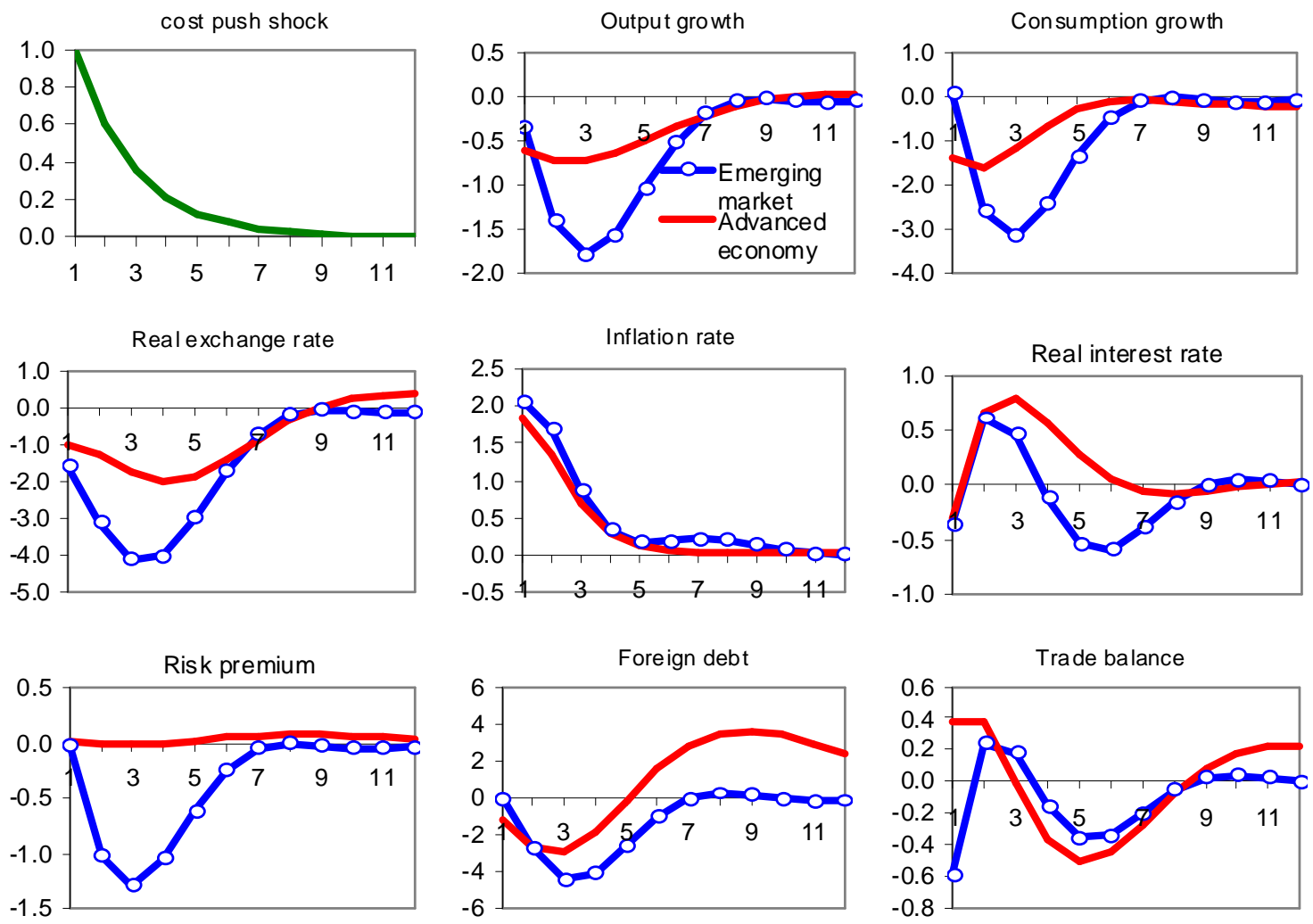

Source: Author's calculations.

24. In the emerging economy, consumption is less forward-looking, so that initially output falls by more than demand, resulting in a trade deficit. In the subsequent period, consumption falls sharply in response to the fall in real income, so that the trade balance swings into surplus. The trade surplus together with the positive balance sheet effect of appreciation, leads in turn to a fall in the risk premium, adding to the real appreciation of the currency. The stronger appreciation of the currency in the emerging economy case contributes to the loss of competitiveness and a weakening of output and the trade balance. The weaker growth profile also allows interest rates to be eased more rapidly than in the advanced economy.

25. In the case of the cost-push shock, the initial real appreciation of the currency helps to dampen the inflationary consequences of the shock, but also tends to worsen the adverse impact on output. Resisting appreciation of the currency would result in higher inflation, but it is unclear how much reduction in the volatility of output might be achieved. Consequently, it is not clear whether dampening the exchange rate movement would, on balance, improve the outcome.

\section{Risk premium shocks}

26. An adverse risk premium shock has generally similar effects on both the advanced and emerging economies (Figure 4). In both cases, the jump in the risk premium leads to 
currency depreciation and a rise in inflation. The real depreciation stimulates exports, boosting GDP, but consumption by forward-looking agents falls, leading to a trade surplus.

27. In both economies, monetary authorities raise interest rates to counter higher inflation and output growth. In the emerging economy, the improved trade balance tends to lower the risk premium, but this is partly offset by the negative balance sheet effect of depreciation. Subsequently, as the economies respond to the firming in the stance of monetary policy, and as the shock gradually unwinds, inflation, growth, the real exchange rate, and the trade balance all gradually return to steady state positions.

Figure 4. Responses to a Risk Premium Shock
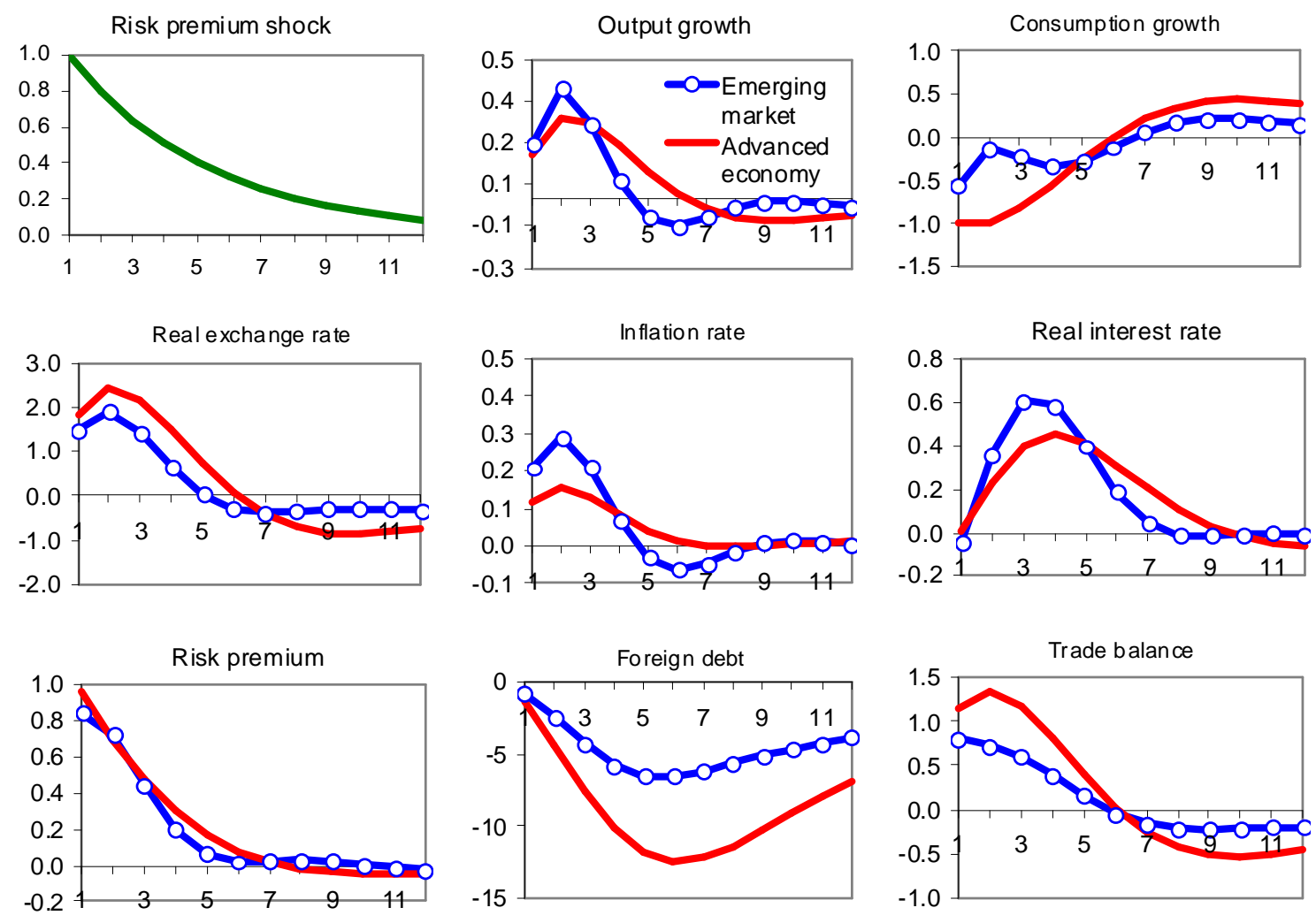

Source: Authors' calculations.

28. In both types of economy, it may be noted, if monetary policy had resisted the downward pressure on the currency in the first instance, this would have led to an earlier and sharper increase in interest rates. Although this would have accentuated the decline in consumption, it would have led to a smaller rise in inflation, as well as dampening the stimulus to net exports. Consequently, some resistance to the exchange rate could lower both inflation and output volatility. However, too strong a resistance to the pressure on the exchange rate could end up worsening performance because, beyond some point, raising interest rates would induce an output contraction and deflation. 


\section{Volatility of Macroeconomic and Financial Variables Under Different Policy Rules}

29. Tables 3a-c report the standard deviations of macroeconomic and financial variables in the advanced, financially-robust economy and the emerging, financially-vulnerable economy, under alternative policy rules, and when exposed to different kinds of shocks. The standard deviations are derived from the simulations as discussed earlier.

Table 3a. Performance of Alternative Policy Rules in Response to Demand Shocks Standard deviations of variables, in percentage points

\begin{tabular}{|c|c|c|c|c|c|c|c|}
\hline Policy rule & Inflation & Output & $\begin{array}{c}\text { Interest } \\
\text { rate }\end{array}$ & $\begin{array}{l}\text { Exchange } \\
\text { rate }\end{array}$ & $\begin{array}{l}\text { Current } \\
\text { account }\end{array}$ & $\begin{array}{c}\text { Inflation } \\
\text { and output } \\
\text { average }\end{array}$ & $\begin{array}{l}\text { Interest rate } \\
\text { and exchange } \\
\text { rate average }\end{array}$ \\
\hline \multicolumn{8}{|c|}{ Advanced, financially robust economy } \\
\hline Taylor rule & 1.06 & 0.81 & 0.87 & 2.83 & 2.50 & 0.93 & 1.85 \\
\hline Plain vanilla & 0.51 & 0.52 & 0.93 & 3.76 & 2.88 & 0.51 & 2.34 \\
\hline $\begin{array}{l}\text { Open economy } \\
(1 / 2 \& 1 / 2)\end{array}$ & 0.63 & 0.55 & 0.88 & 2.94 & 2.63 & 0.59 & 1.91 \\
\hline $\begin{array}{l}\text { Open economy } \\
\text { (XR change) }\end{array}$ & 0.50 & 0.56 & 0.89 & 3.43 & 2.77 & 0.53 & 2.16 \\
\hline $\begin{array}{l}\text { Open economy } \\
\text { (XR level) }\end{array}$ & 0.80 & 0.57 & 0.87 & 2.57 & 2.52 & 0.69 & 1.72 \\
\hline XR-based IT & 1.00 & 0.60 & 0.87 & 2.16 & 2.40 & 0.80 & 1.51 \\
\hline \multicolumn{8}{|c|}{ Emerging, financially vulnerable economy } \\
\hline Taylor rule & 4.07 & 5.78 & 5.13 & 13.00 & 2.40 & 4.93 & 9.06 \\
\hline Plain vanilla & 0.90 & 1.24 & 1.74 & 2.30 & 2.03 & 1.07 & 2.02 \\
\hline $\begin{array}{l}\text { Open economy } \\
(1 / 2 \& 1 / 2)\end{array}$ & 0.88 & 1.09 & 1.69 & 2.12 & 1.93 & 0.99 & 1.91 \\
\hline $\begin{array}{l}\text { Open economy } \\
\text { (XR change) }\end{array}$ & 0.93 & 1.15 & 1.74 & 2.10 & 1.98 & 1.04 & 1.92 \\
\hline $\begin{array}{l}\text { Open economy } \\
\text { (XR level) }\end{array}$ & 1.10 & 1.06 & 1.65 & 2.28 & 1.88 & 1.08 & 1.97 \\
\hline XR-based IT & 1.44 & 0.62 & 1.56 & 2.62 & 1.79 & 1.03 & 2.09 \\
\hline
\end{tabular}

Source: Authors' calculations. 
Table 3b. Performance of Alternative Policy Rules in Response to Cost-Push Shocks

Standard deviations of variables, in percentage points

\begin{tabular}{|c|c|c|c|c|c|c|c|}
\hline Policy rule & Inflation & Output & $\begin{array}{c}\text { Interest } \\
\text { rate }\end{array}$ & $\begin{array}{l}\text { Exchange } \\
\text { rate }\end{array}$ & $\begin{array}{l}\text { Current } \\
\text { account }\end{array}$ & $\begin{array}{c}\text { Inflation } \\
\text { and output } \\
\text { average }\end{array}$ & $\begin{array}{l}\text { Interest rate } \\
\text { and exchange } \\
\text { rate average }\end{array}$ \\
\hline \multicolumn{8}{|c|}{ Advanced, financially robust economy } \\
\hline Taylor rule & 2.38 & 1.43 & 1.31 & 4.64 & 1.66 & 1.90 & 2.98 \\
\hline Plain vanilla & 2.42 & 1.50 & 1.25 & 4.16 & 1.12 & 1.96 & 2.70 \\
\hline $\begin{array}{l}\text { Open economy } \\
(1 / 2 \& 1 / 2)\end{array}$ & 2.71 & 1.28 & 1.25 & 3.27 & 0.92 & 2.00 & 2.26 \\
\hline $\begin{array}{l}\text { Open economy } \\
\text { (XR change) }\end{array}$ & 2.47 & 1.38 & 1.24 & 3.77 & 1.11 & 1.92 & 2.51 \\
\hline $\begin{array}{l}\text { Open economy } \\
\text { (XR level) }\end{array}$ & 2.92 & 1.79 & 1.32 & 5.20 & 1.34 & 2.36 & 3.26 \\
\hline XR-based IT & 2.38 & 1.43 & 1.31 & 4.64 & 1.66 & 1.90 & 2.98 \\
\hline \multicolumn{8}{|c|}{ Emerging, financially vulnerable economy } \\
\hline Taylor rule & 2.46 & 4.89 & 3.34 & 12.90 & 1.40 & 3.68 & 8.12 \\
\hline Plain vanilla & 2.87 & 3.03 & 1.27 & 7.65 & 0.87 & 2.95 & 4.46 \\
\hline $\begin{array}{l}\text { Open economy } \\
(1 / 2 \& 1 / 2)\end{array}$ & 3.91 & 2.65 & 1.33 & 6.45 & 1.03 & 3.28 & 3.89 \\
\hline $\begin{array}{l}\text { Open economy } \\
\text { (XR change) }\end{array}$ & 3.12 & 2.70 & 1.44 & 6.95 & 0.99 & 2.91 & 4.20 \\
\hline $\begin{array}{l}\text { Open economy } \\
\text { (XR level) }\end{array}$ & 4.84 & 2.65 & 1.35 & 6.18 & 1.19 & 3.74 & 3.76 \\
\hline XR-based IT & 5.09 & 2.58 & 0.97 & 5.99 & 1.10 & 3.84 & 3.48 \\
\hline
\end{tabular}

Source: Authors' calculations. 
Table 3c. Performance of Alternative Policy Rules in Response to Risk Premium Shocks Standard deviations of variables, in percentage points

\begin{tabular}{|c|c|c|c|c|c|c|c|}
\hline Policy rule & Inflation & Output & $\begin{array}{l}\text { Interest } \\
\text { rate }\end{array}$ & $\begin{array}{l}\text { Exchange } \\
\text { rate }\end{array}$ & $\begin{array}{l}\text { Current } \\
\text { account }\end{array}$ & $\begin{array}{c}\text { Inflation } \\
\text { and output } \\
\text { average }\end{array}$ & $\begin{array}{l}\text { Interest rate } \\
\text { and exchange } \\
\text { rate average }\end{array}$ \\
\hline \multicolumn{8}{|c|}{ Advanced, financially robust economy } \\
\hline Taylor rule & 0.70 & 0.99 & 0.93 & 6.81 & 3.45 & 0.84 & 3.87 \\
\hline Plain vanilla & 0.26 & 0.54 & 0.88 & 4.91 & 2.81 & 0.40 & 2.90 \\
\hline $\begin{array}{l}\text { Open economy } \\
(1 / 2 \& 1 / 2)\end{array}$ & 0.29 & 0.25 & 0.89 & 3.67 & 2.42 & 0.27 & 2.28 \\
\hline $\begin{array}{l}\text { Open economy } \\
\text { (XR change) }\end{array}$ & 0.36 & 0.42 & 0.87 & 4.33 & 2.62 & 0.39 & 2.60 \\
\hline $\begin{array}{l}\text { Open economy } \\
\text { (XR level) }\end{array}$ & 0.42 & 0.14 & 0.91 & 3.18 & 2.26 & 0.28 & 2.05 \\
\hline XR-based IT & 0.66 & 0.44 & 1.26 & 1.44 & 1.76 & 0.55 & 1.35 \\
\hline \multicolumn{8}{|c|}{ Emerging, financially vulnerable economy } \\
\hline Taylor rule & 2.25 & 2.99 & 3.00 & 9.05 & 1.78 & 2.62 & 6.03 \\
\hline Plain vanilla & 0.44 & 0.56 & 1.04 & 3.23 & 1.53 & 0.50 & 2.13 \\
\hline $\begin{array}{l}\text { Open economy } \\
(1 / 2 \& 1 / 2)\end{array}$ & 0.33 & 0.29 & 0.81 & 2.47 & 1.45 & 0.31 & 1.64 \\
\hline $\begin{array}{l}\text { Open economy } \\
\text { (XR change) }\end{array}$ & 0.50 & 0.38 & 0.92 & 2.84 & 1.58 & 0.44 & 1.88 \\
\hline $\begin{array}{l}\text { Open economy } \\
\text { (XR level) }\end{array}$ & 0.52 & 0.26 & 0.75 & 2.24 & 1.35 & 0.39 & 1.49 \\
\hline XR-based IT & 0.71 & 0.38 & 0.60 & 1.33 & 1.27 & 0.54 & 0.97 \\
\hline
\end{tabular}

Source: Authors' calculations. 